\title{
Ortaokul Öğrencilerinin Erken Dönem Uyumsuz Şemaları İle Duygu Düzenleme Yöntemleri Arasındaki İlişkinin Çeşitli Değişkenler Açısından İncelenmesi $^{1}$
}

\author{
DOI: 10.26466/opus.542052
}

\author{
Mustafa Kılınç- Ayșenur Önder** \\ * Dr. Öğr. Üy, Burdur Mehmet Akif Ersoy Üniversitesi, Eğitim Fakültesi, Merkez/ Burdur/ Türkiye

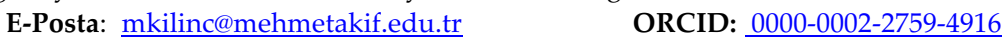 \\ ** Psik. Dan., Tefenni Anadolu İmam Hatip Lisesi, Tefenni/ Burdur/ Türkiye \\ E-Posta: aysenuronderrr@gmail.com ORCID: 0000-0001-5522-6179
}

\begin{abstract}
Öz
Bu araştırmada Burdur ilinde öğrenim gören ortaokul öğrencilerinin erken dönem uyumsuz şemalar ile duygu düzenleme yöntemleri arasındaki ilişkiyi ortaya çıkarılmış ve öğrencilere ait bazı değişkenlere göre anlamlı düzeyde farklılaşmanın olup olmadığını belirlenmiştir. Araştırmanın çalışma grubunu, 2017-2018 öğretim yılında Burdur merkezinde öğrenim gören 1629 öğrenci oluşturmaktadır. Araştırmanın verileri, "1016 Yaş Çocuk ve Ergenler İçin Erken Dönem Uyumsuz Şema Ölçekler Takımı (ÇEŞÖT)" ve "Ergenler İçin Duygu Düzenleme Ölçeği (EIDDÖ)" ile toplanmıştır. Verilerin çözümlenmesinde Bağımsız Örneklem T Testi, Tek Yönlü Varyans Analizi, Pearson Momentler Çarpım Korelasyonu, Doğrusal Regresyon Analizi kullanılmıştır. Araştırma sonuçlarına göre erkek öğrencilerde uyumsuz şemaların daha fazla olduğu görülmüştür. Duygu düzenleme yöntemlerinin cinsiyete göre alt boyutlarda anlaml düzeyde faklllk olduğu görülmüştür. Öğrencilerin erken dönem uyumsuz şemaları anne ve baba eğitim düzeyine göre eğitim seviyesi yükseldikçe uyum bozucu şemaların varlı̆̆ azalmaktadır. Erken dönem uyumsuz şemalar ile duygu düzenleme yöntemleri arasında orta ya da düşük düzeyde ilişki bulunmuş ve ilişkinin yönü alt boyutlara göre değişiklik göstermiştir. Ayrıca uyumsuz şemaların duygu düzenleme yöntemlerini yordama düzeyi incelenmiş ve "Zedelenmiş Özerklik ve Performans" şema alanı ve "Başkalarına Yönelimlilik" şema alanının varyansın \%33'ünü açıkladığı, "Kopukluk ve Reddedilmişlik" şema alanının ise varyansın \%21'ini açıkladı̆̆ görü̈lmüştür. Ayrıca işlevsel olmayan duygu düzenleme yöntemlerinin farklı uyumsuz şemaları yordadı̆̆ı görü̈lmüştür.
\end{abstract}

Anahtar Kelimeler: Duygu Düzenleme, Duygu Regülasyonu, Erken Dönem Uyumsuz Şemalar, Ergenler

\footnotetext{
${ }^{1}$ Bu makale, Ayșenur Önder'in "Ortaokul Öğrencilerinin Erken Dönem Uyumsuz Şemaları ile Duygu Düzenleme Yöntemleri Arasındaki Iliş̧kinin Incelenmesi" adlı Yüksek Lisans tezinden üretilmiştir. Bu tez çalışması BAP tarafindan desteklenmiştir. Proje No: 0496-YL-18
} 


\title{
An Investigation of The Relationship Between Early Maladaptive Schemas of Secondary School Students And Emotion Regulation Methods in Terms of Various Variables
}

\begin{abstract}
In this study, the relationship between early period in compatible schemas and emotion regulation methods of secondary school students studying in Burdur was revealed and it was determined whether there was a significant difference according to some variables. The study group consisted of 1629 students in the center of Burdur in 2017-2018 academic year. The data of the study were "Early Maladaptive Schema Questionnaires Set for Children and Adolescents between the ages of 10-16" and "The Regulation of Emotions Questionnaire". Independent- Samples t test, OneWay ANOVA, Pearson moments correlation, linear regression analysis were used for data analysis. According to research results it's seen that there are more maladaptive schemas among male students. Gender based general scale points in emotion regulation methods shows significant differences. Maladaptive schemas differ based on the educational level of parents and as the education level rises, the presence of maladaptive schemas decreases. When the relation between early maladaptive schemas and emotion regulation methods is studied, a relation is found at middle and lower level and the direction of the relations how edvariance to the lowerlevels. Maladaptive schemas' predictive level of emotion regulation is studied and it's seen that "Impaired Autonomy and Performance" and "Other Directedness" schema field explains $33 \%$ of the variance and "Disconnection and, Rejection" schema field explains $21 \%$ of the variance.
\end{abstract}

Keywords: Early Maladaptive Schemas, Emotion Regulation, Adolescent 


\section{Giriş}

Şema terapi, Young (1990) tarafından geliştirilmiş; geleneksel, bilişsel ve davranışçı tedavileri, kavramları genişletilmiş yenilikçi ve bütünleştirici bir terapidir. Özellikle psikopatolojik rahatsızlıkların tedavisinde kullanılmak için yeni bir sistem sağlar. Young (1990) kuramında "şema"lardan bahseder ve bu şemaların çoğunun özellikle çocukluk ve ergenlik deneyimlerinin sonucu olarak geliştiğini ve yaşamımız boyunca tekrarlanan kendilik yıkıcı duygusal ve bilişsel örüntüler olduğunu belirtir. Ayrıca bu durumun psikopatolojik sorunlara yol açabilen bir faktör olduğuna vurgu yapar.

Şemaların kazanılmasında ve etkililiğinin artmasında önemli etkene sahip 4 tür erken dönem yaşam deneyimi vardır. İlki çocukluk yaşantısında ihtiyaçların karşılanmamasında ortaya çıkar, çocuk anlayış veya sevgiden yoksundur. Bu durumda oluşan eksiklik çocuğun zihninde kalıcı hale gelir. İkinci deneyimde güvenlik ihtiyacı karşılanmayarak geçmiş yaşamda yaşanan travmanın etkisiyle çocuğun zarar görmesi, mağdur olması halinde acı, tehdit, tehlikeyi yansıtan şemalar gelişir. Bu durumlar çocukta kaygı, umutsuzluk, güvensizlik şemalarının oluşmasına zemin hazırlar. Üçüncü türde, çocuğa ebeveynler tarafından olması gerekenden fazla olanak sunulur. İhtiyaçlarından fazlası çocuğa verilir. Genellikle çocuğa kötü davranılmaz, şımartılır ve üzerine düşülür. Böyle bir durumda çocukta özerklik durumu, sınırların olması gibi temel ihtiyaçlar karşılanmaz. Dördüncü tip yaşam deneyiminde ise çocuğun seçici özdeşimi, içselleştirmesi söz konusudur. Çocuk ebeveynini model alarak düşüncelerini, duygularını, davranışlarını içselleştirir, ebeveynle özdeşleşir. Bu durumda oluşan özdeşim ve içselleştirme şemaya dönüşebilir. Çocukluk çevresi şemanın gelişiminde önemli bir rol oynadığı gibi çevresi dışındaki durumlarda etkileyebilir, tetikleyici olabilir. Yani şemalar çocuğun kendi mizacı ve şekillendirici çevre arasındaki etkileşimle ortaya çıkar (Rafaeli, Bernstein ve Young, 2011; Young, Kolosko ve Weishaar, 2003).

Çocuğun gelişimsel ihtiyaçları karşılanmadığında uyum bozucu şemalar gelişir. Uyum bozucu şemalar, kişinin kendisiyle, diş dünyayla ve diğer insanlarla ilgili sahip olduğu inançları içeren yapılardır. Bu şemalar 
temel çocukluk ihtiyaçlarının giderilmemesinden, kalıtsal mizaçtan ve erken dönemde çevrenin etkileşiminden ortaya çıar (Farrell, Reiss ve Shaw, 2012).

Young vd. göre (2003) erken dönem uyumsuz şemaların geniş bir tanımı yapılacak olursa; erken dönem uyumsuz şemalar:

- Geniş, yaygın tema ya da yapılardır.

- Hatıralardan, duygulardan, bilişlerden ve bedensel duyulardan oluşur.

- Bir kişinin kendini ve başkalarıyla olan ilişkilerini dikkate alır.

- Çocukluk veya ergenlik boyunca gelişir.

- Kişinin yaşamı boyunca işlenmeye, gelişmeye devam eder, karmaşıklaşır.

- Önemli bir dereceye kadar işlevsizdir.

Şema alanları; "Ayrılma ve Dışlanma / Reddedilme", "Zedelenmiş Özerklik ve Performans", "Zedelenmiş Sınırlar", "Başkalarına Yönelimlilik" ve "Aşırı Tetikte Olma Baskılama / Ketleme" olarak 5 katagoriye ayrılmıştır. Ayrıca bu beş alan; Terk Edilme / İstikrarsızlık, Kuşkuculuk / Kötüye Kullanılma, Duygusal Yoksunluk, Kusurluluk / Utanma, Sosyal İzolasyon, Bağımlılık / Yetersizlik, Hastalık ve Tehditlere Karşı Dayanıksızlık, Yapışıklık / Gelişmemiş Benlik, Başarısızlık, Haklılık / Büyüklenmecilik, Yetersiz Özdenetim, Boyun Eğicilik, Kendini Feda Etme, Onay Arayıcılık, Karamsarlık, Duyguları Bastırma, Yüksek Standartlar ve Aşırı Eleştiricilik ve Cezalandırıcılık olarak 18 alt boyuta ayrılmıştır.

Çocukluk çağında edinilen deneyimler, erken dönem uyumsuz şemaların ana temelini oluşturur. Bu dönemde gelişen temalar, bireyin bulunduğu aile içinde ortaya çıkar. Sonrasında ise şemanın gelişimine bireyin çocukluk dönemindeki deneyimleri arkadaş çevresi, eğitim aldığı okul, bulunduğu çevre, yaşadığı kültür gibi diğer etkenler neden olabilir. Fakat sonraki dönemdeki gelişmiş olan şemalar genelde çok yaygın ya da önceki dönemde gelişmiş olanlar kadar güçlü değildir (Young, 1990). Yani erken dönemde oluşmuş olumsuz şemalar bireyin yaşamını doğrudan ya da dolaylı olarak etkileyebilmektedir ve çeşitli psikopatolojik sorunlara yol açabilmektedir. Ayrıca yapılan araştırmalar da bu görüşü desteklemektedir (Harris ve Curtin, 2002; Riso vd., 2006; Köse, 2009; Colman, 2010; Eberhart, Auerbach, Bigda-Peyton ve Abela, 2011; Thimm, 2011; Gök, 2012; Ünal, 
2012; Calvete, Orue ve Hankin, 2014; Sarıtaş ve Gençöz, 2015; Yiğit ve Erden, 2015).

$\mathrm{Bu}$ araştırmada ele alınan bir diğer kavram ise duygu düzenlemedir. Duygu düzenlenme üzerinde yapılan araştırmalar son yıllarda hızla artmaktadır. Bu alanda Gross ve Thompson (2007) duygusal düzenlemenin bilimsel çalışmalara konu olmasının sebebini iki farklı teorik yaklaşım olmasından kaynaklandığını söyler. İlk yaklaşım gelişimsel psikoloji yaklaşımıdır. Bu yaklaşımın kökeni işlevsel teoriye dayanır ve duygu düzenlemede gelişimsel sürece odaklanır. Diğer yaklaşım ise kişilik psikolojisi yaklaşımıdır. Kökeni; stres ve başa çıkma yöntemleri ile ilgili araştırmalara, savunma mekanizmalarının psikanalitik boyutuyla alakalı araştırmalara ve işlevsel duygu teorisine dayanır. Aynı zamanda son yıllardaki çalışmalar, duygu düzenleme oluşumunu netleştirmeye çalışmaktadır ve duygu düzenleme ile ilgili tam olarak kesin bir tanım yapılamasa da Thompson, duygu düzenlemeyi şu şekilde tanımlamıştır: "Duygu düzenlemesi, bireyin amaçlarını gerçekleştirmek için duygusal reaksiyonları (özellikle de bu tepkilerin yoğun ve geçici özelliklerini) izlemek, değerlendirmek, düzenlemekten ve değiştirmekten sorumlu içsel ve dişsal süreçlerdir."(Thompson, 1994, s. 27-28).

Duygu düzenleme sirasında insanlar olumlu veya olumsuz duygularını sürdürebilir, azaltabilir veya arttırabilirler. Dolayısıyla duygu düzenleme daha çok duygusal tepkilerdeki değişimleri içermektedir. Bu değişimler bireylerin yaşadıkları duyguların çeşidinde, duyguların yaşandığı sırada ve bu duyguların nasıl yaşandığ sini gösterebilir (Gross, 1999, akt. Duy ve Yıldız, 2014). Duygu düzenlemenin insanların yaşadıkları duygularda etkisi olmasından dolayı, etkileri duygusal tepki vermenin tüm faktörlerinde (düşünce, davranış, fizyoloji ve duygular) gözlenebilir (Koole, 2010, akt. Duy ve Yıldız, 2014).

Duygu düzenlemenin Gross' a göre (2014) üç temel özelliği vardır. İlk temel özelliği, duygu sürecini modifiye etme hedefinin aktivasyonudur (Gross, Sheppes ve Suri, 2011). Bu hedef kişinin kendisinde veya başka bir kişide aktif hale getirilebilir. Yetişkinlerde çalışma yapan araştırmacılar tipik olarak içsel duygu düzenlemeye odaklanırlar. Buna karşlık bebekler ve çocuklar ile çalışan araştırmacılar tipik olarak dışsal duygu düzenlemeye odaklanırlar (Cole, Martin ve Dennis, 2004). Bu ayrımın genellikle 
yararlı olmasına rağmen, bazı durumlarda içsel ve dışsal duygu düzenlemelerinin birlikte ortaya çıktığı durumlar James Gross' un çalışmalarında mevcuttur (Gross, 2014). İkinci temel özellik duygu düzenlemede duygu yörüngesini değiştirmekle sorumlu olan süreçlerin devreye girmesidir. Duyguları düzenlemek için pek çok farklı süreç toplanabilir ve bunlar açık ve örtük oldukları dereceye kadar önemli ölçüde farklılık gösterir (Gross, 2014). Duygu düzenlemenin üçüncü temel özelliği duygu dinamikleri üzerindeki etkileşim ya da deneyimsel, davranışsal ya da fizyolojik alanlardaki gecikmelerin, yükselme süresinin, büyüklüğünün, süresinin dengelenmesidir (Thompson, 1991). Duygu düzenleme bireyin hedeflerine bağlı olarak, duygusal cevabın gecikmesini, yükselme süresini, büyüklügünü, süresini veya dengelenmesini artırabilir veya azaltabilir (duygu düzenleme yokluğunda meydana gelebilecek duygusal tepkiyle karşılaştırıldığında). Duygu düzenlemenin bu 3 temel özelliği -düzenleyici bir hedefin aktivasyonu, düzenleyici süreçlerin devreye girmesi ve duygu yörüngesinin modülasyonu- birçok farklı duygu düzenleme tipinin ortak özellikleridir (Gross, 1998).

Son yıllarda erken dönem uyumsuz şemalar ve duygu düzenleme ilgili araştırmalar artmış olsa da özellikle ergenlik dönemindeki kişilerin duygu düzenleme yöntemleri ile erken dönem uyumsuz şemalar arasındaki ilişkinin yordanmasıyla ilgili alanyazın incelendiğinde yapılan bir araştırma bulunmadığı görülmektedir. Bundan dolayı yapılan çalışmada, bir risk faktörü olarak erken dönem uyumsuz şemaların, duygu düzenleme yöntemleri ile ilişkisi incelenmiştir. Bu bağlamda erken dönem uyumsuz şemalara sahip olan ortaokul öğrencilerinin duygu düzenleme durumlar1nın bilişsel, duygusal ve davranışsal yönden işlevsel olup olmadığını hem içsel hem dışsal kaynaklı etmenler üzerinden değerlendirerek bu öğrencilerin sahip oldukları uyumsuz şemalarının duygu düzenleme yöntemlerini belirlemede bir rol oynayıp oynamadığı araştırılmıştır.

Bahsedilenler ışı̆̆ında araştırmanın problem cümlesini "Ortaokula giden öğrencilerin erken dönemde oluşan uyumsuz şemaları ile duygu düzenleme yöntemleri arasında anlamlı ilişki var mıdır?" sorusu oluşturmaktadır. Bu doğrultuda araştırmanın amacı, Burdur ilinde öğrenim gören ortaokul öğrencilerinin erken dönem uyumsuz şemaları ile duygu düzenleme yöntemleri arasında ilişki olup olmadığının belirlenmesi ve öğ- 
rencilere ait bazı değişkenlere göre ölçeklerden elde edilen puanlar arasında istatistiksel olarak anlamlı düzeyde farklılaşmanın olup olmadığını tespit etmektir.

Araştırma kapsamında belirlenen problem cümlesinden yola çıkarak aşağıdaki alt problemlere cevap aranmıştır:

1. Öğrencilerin uyumsuz şemaları;

a. Cinsiyete,

b. Anne eğitim düzeyine,

c. Baba eğitim düzeyine göre anlamlı bir farklılık göstermekte midir?

2. Öğrencilerin duygu düzenleme yöntemleri;

a. Cinsiyete,

b. Anne eğitim düzeyine,

c. Baba eğitim düzeyine göre anlamlı bir farklılık göstermekte midir?

3. Ortaokul öğrencilerinin erken dönem uyumsuz şemaları ile duygu düzenleme yöntemleri arasında anlamlı düzeyde bir ilişki var midır?

4. Ortaokul öğrencilerinin erken dönem uyumsuz şemaları, öğrencilerin duygu düzenleme yöntemlerini anlamlı düzeyde yordamakta midır?

\section{Yöntem}

Bu bölümde araştırma modeli, çalışma grubu, veri toplama aracı, verilerin toplanması ile ilgili bilgiler yer almaktadır.

\section{Araştırmanın Modeli}

Araştırma ilişkisel tarama modeli niteliğindedir. İlişkisel tarama modelinde, birden fazla değişken arasındaki birlikte değişimin varlığını, derecesini belirlemek amaçlanmaktadır (Karasar, 2009). 


\section{Evren Örneklem}

Araştırmanın çalışma evrenini, 2017-2018 eğitim-öğretim yılında Burdur ili Merkez ilçesinde öğrenim gören 3680 ortaokul öğrencileri oluşturmaktadır. Çalışma evrenini temsil edebilecek örneklemi belirlemek için örnekleme hatası olarak 0,03 , güven aralığ $1 \% 99$ ve ilgilenilen olayın veya olgunun olma olasılığı olarak \%50 belirlenmiştir. Bu bilgiler ışığında çalışma evrenini temsil edebilecek örneklem miktarı 1229 olarak hesaplanmıştır. Araştırmanın örnekleminin hesaplanmasında aşağıda yer alan eşitlik kullanılmıştır:

$$
=\frac{n_{0}}{1+\frac{n_{0}}{N}} \quad(\text { Eşitlik 3.1) }
$$

Eşitlik 3.1'de yer alan $\mathrm{n}_{0}, \mathrm{n}_{0}=\left(\mathrm{t}^{2} \mathrm{PQ}\right) / \mathrm{d}^{2}$ eşitliği ile hesaplanmakta ve bu formülde yer alan $\mathrm{d}^{2 `}$ deki $\mathrm{d}$ değeri araştırma evreninin özelliğine ilişkin yapılacak tahminle ilgili göz ardı edilmek istenen aralık genişliğini tanımlamaktadır (Büyüköztürk, Çakmak, Akgün, Karadeniz ve Demirel, 2012, s. 93). Toplanan verilerden 2051 tanesi birden fazla şıkkı işaretleme, bir kısmını yanıtlamama gibi çeşitli nedenlerle geçersiz olmuş, kalan 1629 tanesi veri analizine alınmıştır. Ortaokul düzeyinde öğrenim gören 1629 öğrenci belirlenen çalışma evrenini temsil edebilecek örneklem büyüklügü̈nde olduğu görülmektedir.

Tablo 1.Araştırmaya Katılan Öğrencilerin Demografik Özellikleri

\begin{tabular}{|c|c|c|c|}
\hline Demografik Değişkenler & Gruplar & $\mathrm{N}$ & $\%$ \\
\hline \multirow[t]{3}{*}{ Cinsiyet } & $\mathrm{K} 1 \mathrm{z}$ & 928 & 57,0 \\
\hline & Erkek & 701 & 43,0 \\
\hline & Toplam & 1629 & 100 \\
\hline \multirow[t]{8}{*}{ Anne Eğitim Düzeyi } & Okur-Yazar Değil & 32 & 2,0 \\
\hline & Okur-Yazar & 25 & 1,5 \\
\hline & İlkokul & 424 & 26,0 \\
\hline & Ortaokul & 316 & 19,4 \\
\hline & Lise & 482 & 29,6 \\
\hline & Fakülte/Yüksekokul & 299 & 18,4 \\
\hline & Lisansüstü & 51 & 3,1 \\
\hline & Toplam & 1629 & 100 \\
\hline \multirow[t]{8}{*}{ Baba Eğitim Düzeyi } & Okur-Yazar Değil & 16 & 1,0 \\
\hline & Okur-Yazar & 24 & 1,5 \\
\hline & İlkokul & 266 & 16,3 \\
\hline & Ortaokul & 323 & 19,8 \\
\hline & Lise & 495 & 30,4 \\
\hline & Fakülte/Yüksekokul & 417 & 25,6 \\
\hline & Lisansüstü & 88 & 5,4 \\
\hline & Toplam & 1629 & 100 \\
\hline
\end{tabular}


Tablo 1'de görüldüğü gibi araştırmaya Burdur merkezinde öğrenim gören 928 kız ve 701 erkek, toplamda 1629 öğrenci katılmıştır. Öğrencilerin annelerinin \% 62.7'si çalışmamakta ve çalışanların ise meslek grupları \%3.5-16.3 arasında değişmektedir. Eğitim düzeyi açısından bakıldığında annelerin \%48.9'u okur-yazarlık durumu, ilkokul ve ortaokul eğitim düzeyine, \%51.1'i ise lise ve sonrası eğitim düzeyine sahiptir. Babaların \%38.6's1 okur-yazarlık durumu, ilkokul ve ortaokul eğitim düzeyine, $\% 61.4$ 'ü ise lise ve sonrası eğitim düzeyine sahip olduğu görülmektedir.

\section{Verilerin Toplanması ve Veri Toplama Araçları}

Araştırmanın verileri, "Kişisel Bilgi Formu", "10-16 Yas, Çocuk ve Ergenler için Erken Dönem Uyumsuz Ş̧ema Ölçekler Takımı (ÇEŞÖT)" ve "Ergenler İçin Duygu Düzenleme Ölçeği (EIDDÖ)" uygulanmıştır. Katılımc1lardan cevaplayacakları ölçekler üzerine kimlik bilgilerini yazmamaları istenmiştir. Uygulamadan önce katılımcılara ölçeklerle ilgili yönergeler okunmuş ve uygulamayla ilgili bilgi verilmiştir. Kişisel bilgi formu araştırmacı tarafından ortaokul öğrencilerinin bazı kişisel bilgilerini (cinsiyet, anne-baba eğitim durumu vb.) belirlemek amacıyla hazırlanmıştır.

\section{0-16 Yas, Çocuk ve Ergenler İçin Erken Dönem Uyumsuz Şema Ölçekler} Takımı (ÇEŞÖT): Güner (2013) tarafından doktora tezinde geliştirilen ÇEŞÖT toplam 97 maddeden ve yorumlanabilir beş ayrı gereksinme alanı ve 15 faktörden oluşan geçerli, güvenilir bir ölçek olarak kabul edilmiştir. Alt ölçekler sırasıyla, kopukluk ve reddedilmişlik gereksinme alanı içinde kusurluluk / utanma, kuşkuculuk / kötüye kullanılma, duygusal yoksunluk, terk edilme ve tutarsızlık; zedelenmiş özerklik ve performans alanı içinde başarısızlık, bağımlılık / yetersizlik, yapışıklık ve gelişmemiş benlik, hastalık ve tehditlere karşı dayanıksızlık; zedelenmiş sınırlar alanı içinde haklılık / büyüklenmecilik yetersiz özdenetim, başkalarına yönelimlilik gereksinme alanı içinde boyun eğicilik, kendini onaylamama, onay arayıcılık; aşırı tetikte olma ve baskılama / ketleme; gereksinme alanı içinde karamsarlık, cezalandırıcılıktır. Katılımcılar, her maddeyi beşli likert üzerinde (1=Benim için tamamıla yanlış, 5=Benim için tamamıyla doğru) derecelendirmektedir. 
10-16 Yaş Çocuk ve Ergenler İçin Erken Dönem Uyumsuz Şema Ölçekler Takımı'nın Cronbach Alfa katsayısı sırasıyla, kopukluk ve reddedilmişlik gereksinme alanı . 89, bu alan içinde yer alan kusurluluk / utanma .61, kuşkuculuk / kötüye kullanılma .77, duygusal yoksunluk .81, terk edilme ve tutarsızlık .64; zedelenmiş özerklik ve performans alanı .85 ve bu alan içinde başarısızlık .77, bağımlılık / yetersizlik .75, yapışıklık ve gelişmemiş benlik .68, hastalık ve tehditlere karşı dayanıksızlık .68; zedelenmiş stnırlar alanı .86 ve bu alan içinde haklılık / büyüklenmecilik .84, yetersiz özdenetim .72; başkalarına yönelimlilik. 78 ve bu gereksinme alanı içinde boyun eğicilik .67, kendini onaylamama .73, onay arayıcllık .66; aşırı tetikte olma ve baskılama / ketleme .82 ve bu gereksinme alanı içinde karamsarlık .83, cezalandırıcılık .55 olarak bulunmuştur.

Yapılan bu çalışmada ise ÇEŞÖT Cronbach Alfa katsayısı sırasıyla, kopukluk ve reddedilmişlik gereksinme alanı . 89, bu alan içinde yer alan kusurluluk / utanma .64, kuşkuculuk / kötüye kullanılma .77, duygusal yoksunluk .85, terk edilme ve tutarsizlık .62; zedelenmiş özerklik ve performans alanı .87 ve bu alan içinde başarısızlık .81, bağımlılık / yetersizlik .75, yapışıklık ve gelişmemiş benlik .58, hastalık ve tehditlere karşı dayanıksızlık .64; zedelenmiş sınırlar alanı .89 ve bu alan içinde haklılık / büyüklenmecilik .87, yetersiz özdenetim .67; başkalarına yönelimlilik .84 ve bu gereksinme alanı içinde boyun eğicilik .72, kendini onaylamama .74, onay arayıcılık .62; aşırı tetikte olma ve baskılama / ketleme .85 ve bu gereksinme alanı içinde karamsarlık .84, cezalandırıcılık .59 olarak bulunmuştur. Bu değerlerin Güner (2013) çalışmasında elde ettiği güvenirlik katsayısı değeri ile benzerlik göstermektedir.

Ergenler İçin Duygu Düzenleme Ölçeği (EIDDÖ): Phillips ve Power (2007) tarafından geliştirilen, Duy ve Yıldız (2014) tarafından Türkçeye uyarlanan Ergenler İçin Duygu Düzenleme Ölçeği (EİDDÖ) “Hiçbir zaman (1), Nadiren (2), Bazen (3), Çoğu zaman (4) ve Her zaman (5)" şeklinde likert tipi beşli derecelendirmeye sahiptir. Ölçeğin doğrulayıcı faktör analizi sonucunda 18 maddeden ve dört boyuttan oluşan duygu düzenleme modelin iyi uyum verdiği görülmüştür $(\chi 2=517.94, \mathrm{sd}=129$, RMSEA= .06 , RMR= .09 , SRMR $=.06, \mathrm{GFI}=.94, \mathrm{AGFI}=.92, \mathrm{CFI}=.93, \mathrm{NFI}=.91$ ve $\mathrm{NNFI}=.92) . \mathrm{Er}-$ genler İçin Duygu Düzenleme Ölçeği'ninCronbach Alfa katsayısı sırasıyla dışsal işlevsel olmayan duygu düzenleme alt boyutu için .76, içsel işlevsel 
olmayan duygu düzenleme alt boyutu için .68, içsel işlevsel duygu düzenleme alt boyutu için .74 ve dışsal işlevsel duygu düzenleme alt boyutu için .59 olarak bulunmuştur.

Yapılan bu çalışmada ise EIDDÖ genel ölçeğin güvenilirlik katsayısının $(\alpha) .68$, içsel işlevsel duygu düzenleme alt boyutunda güvenilirlik katsayısının .74, içsel işlevsel olmayan duygu düzenleme alt boyutunda .72, dışsal işlevsel duygu düzenleme alt boyutunda .55 ve dişsal işlevsel olmayan duygu düzenleme alt boyutunda güvenilirlik katsayısının .75 olduğu görülmektedir. Bu değerler Duy ve Yıldız (2014) çalışmalarında elde ettiği güvenirlik katsayısı değeri ile benzerlik göstermektedir.

\section{Verilerin Analizi}

Araştırmanın amacı doğrultusunda cevapları aranan alt problemlere yönelik ilk olarak katılımcıların sosyo-demografik değişkenleri ölçen ölçeklere ilişkin bilgilerini elde edebilmek amacıyla betimleyici analizler yapılmıştır. Verilerin analizine geçmeden önce alt problemlerde yapılacak analiz yöntemlerini belirlemek amacıyla verilerin normal dağılıp dağılmadıklarını gösteren Skewness- Kurtosis Normallik testi yapılmıştır.

Öğrencilerin uyumsuz şemalarının ve duygu düzenleme yöntemlerinin cinsiyete göre göre farklılık gösterip göstermediğini belirlemek amacıyla bağımsız örneklem t-testi; diğer alt problemlerde ise tek yönlü varyans analizi (OneWay ANOVA) kullanılmıştır. Yapılan analizlerde anlamlılık değeri, .05 olarak alınmıştır.

Araştırmada ortaokul öğrencilerinin erken dönem uyumsuz şemaları ile duygu düzenleme yöntemleri arasındaki ilişkiyi belirlemek için Pearson Momentler Çarpım Korelâsyon Tekniği uygulanmıştır. Ayrıca araştırmada alt probleme göre doğrusal regresyon analizinde stepwise tekniği kullanılarak yordama düzeyine bakılmıştır.

\section{Bulgular}

Bu bölümde araştırma bulguları ve bu bulgulara dayalı olarak yapılan yorumlar yer almaktadır. Araştırmadan elde edilen bulgular ve yorumlar, araştırmanın alt problemleri doğrultusunda sunulmuştur. 


\section{Ortaokul Öğrencilerinin Ergenler İçin Duygu Düzenleme Ölçeğgine (EIDDÖ) İlişkin Görüşleri}

Araştırmaya katılan ortaokul öğrencilerinin EİDDÖ’ye ilişkin görüşlerinin ne düzeyde olduğunu belirlemek için aritmetik ortalama $(\bar{x})$ ve standart sapma (SS) değerlerinden yararlanılmıştır. Tablo 3' de görüldüğü gibi genel ölçekten elde edilen puanların ortalamalarına göre ortaokul öğrencilerinin EIDDÖ'ye ilişkin görüşleri $(\bar{x}=2.66)$ "nadiren" düzeyindedir. Elde edilen bulgulara göre ortaokul öğrencilerinin duygu düzenleme yöntemine ilişkin içsel işlevsel ve dişsal işlevsel duygu düzenleme yöntemlerini içsel işlevsel olmayan ve dişsal işlevsel olmayan duygu düzenleme yöntemine göre daha çok kullandıkları söylenebilir. Ayrıca ortaokul öğrencilerinin duygu düzenleme yöntemlerinin en çok içsel işlevsel olduğu ve en az ise dışsal işlevsel olmayan duygu düzenleme yöntemin olduğu söylenebilir.

Tablo 3.Ortaokul Öğrencilerinin Ergenler İçin Duygu Düzenleme Ölçeği'ne İlişkin Görüşleri

\begin{tabular}{lll}
\hline Ölçek ve Boyutlar & $\bar{x}$ & SS \\
\hline Ė̇DDÖ genel ölçek & 2.66 & .47 \\
1. İçsel İsslevsel & 3.86 & .78 \\
2. İçsel İşlevsel Olmayan & 2.35 & .86 \\
3. Dişsal İşlevsel & 2.97 & .90 \\
4. Dişsal İşlevsel Olmayan & 1.76 & .76 \\
\hline
\end{tabular}

Tablo 4'de görüldüğü gibi genel ölçekten elde edilen puanların ortalamalarına göre ortaokul öğrencilerinin ÇEŞÖT'e ilişkin görüşleri $(\bar{x}=2.26)$ "benim için çoğunlukla yanlış" düzeyindedir. Elde edilen bulgulara göre ortaokul öğrencilerinin gereksinme alanlarına ilişkin görüşlerinin genel olarak aynı düzeyde olduğu söylenebilir. Ayrıca öğrencilerin yapışıklık ve gelişmemiş benlik şemasına, hastalık ve tehditlere karşı dayanıksızlık şemasına ve onay arayıcılık şemasına ilişkin aldıkları puanların diğer alt boyutlara göre daha fazla olduğu söylenebilir. 
Tablo 4. Ortaokul Öğrencilerinin ÇEŞÖT'e İlişkin Görüşleri

\begin{tabular}{lll}
\hline Ölçek ve Boyutlar & $\bar{x}$ & SS \\
\hline ÇEŞÖT genel ölçek & 2.26 & .66 \\
\hline A)Kopukluk ve Reddedilmişlik & 2.21 & .75 \\
1. Kusurluluk / Utanma & 2.21 & .85 \\
2. Kuşkuculuk ve Kötüye Kullanılma & 2.30 & .88 \\
3. Duygusal Yoksunluk & 2.02 & .86 \\
4. Terk Edilme ve Tutarsızlık & 2.30 & .95 \\
B)Zedelenmiş Özerklik ve Performans & 2.51 & .71 \\
1. Başarısızlık & 2.10 & .86 \\
2. Bağımlılık / Yetersizlik & 2.11 & .82 \\
3. Yapışıklık ve Gelişmemiş Benlik & 3.09 & 1.08 \\
4. Hastalık ve Tehditlere Karşı Dayanıksızlık & 2.76 & 1.13 \\
C)Zedelenmiş Sınır & 2.22 & .75 \\
1. Haklılık / Büyüklenmecilik & 2.18 & .76 \\
2. Yetersiz Özdenetim & 2.27 & .89 \\
D)Başkalarına Yönelimlilik & 2.27 & .73 \\
1. Kendini Onaylamama & 1.97 & .89 \\
2. Boyun Eğicilik & 2.16 & .81 \\
3. Onay Arayıcılık & 2.69 & 1.00 \\
E)Aşırı Tetikte Olma Baskılama / Ketleme & 2.41 & .81 \\
1. Karamsarlık & 2.47 & .97 \\
2. Cezalandırııılık & 2.35 & .84 \\
\hline
\end{tabular}

Öğrencilerin Erken Dönem Uyumsuz Şema Puanlarnın ve Duygu Düzenleme Yöntemleri Puanlarının Cinsiyet Bakımından Karşılaştırılması

Çalışma grubunda yer alan öğrencilerin erken dönem uyumsuz şema alanlarından aldıkları puanların ve duygu düzenleme yöntemlerinden aldıkları puanların cinsiyet bakımından farklılaşıp farklılaşmadığını belirlemek için bağımsız gruplar arasında yapılan $t$ testi kullanılmıştır.

Tablo 5'de görüldüğ ü gibi ÇEŞÖT'e göre genel olarak cinsiyet farkı değerlendirildiğinde cinsiyete göre erkeklerin lehine anlamlı bir farklılık gösterdiği görülmektedir $[t(1627)=2.54, \mathrm{p}<.05]$. Alt boyutlarda erken dönem olumsuz şema alanları ayrı ayrı değerlendirildiğinde duygusal yoksunluk şemasında $\left[t_{(1627)}=-2.22, \mathrm{p}<.05\right]$ ve Başarısızlık şemasinda $\left[t_{(1627)}=-2.35, \mathrm{p}<\right.$ .05] cinsiyet açısından anlamlı fark olduğu ve erkeklerde daha fazla olduğu görülmektedir. Yapışıklık ve Gelişmemiş Benlik şemasında [ $t(1627)=$ 3.84, $\mathrm{p}<.05$ ] ve Hastalık ve Tehditlere Karşı Dayanıksızlık şemasında $\left[t_{(1627)}=4.13, \mathrm{p}<.05\right]$ cinsiyet açısından anlamlı fark olduğu ve kadınlarda daha fazla olduğu görülmektedir. 
Haklılık / Büyüklenmecilik şemasında [ $\left.t_{(1627)}=-5.07, \mathrm{p}<.05\right]$, Yetersiz Özdenetim şemasında $[t(1627)=-5.08, \mathrm{p}<.05]$, Kendini Onaylamama şemasinda $\left[t_{(1627)}=-3.87, \mathrm{p}<.05\right]$, Boyun Eğicilik şemasinda $\left[t_{(1627)}=-4.38, \mathrm{p}<.05\right]$ ve Onay Arayıcılık şemasında $[t(1627)=-5.38, p<.05]$ cinsiyet açısından anlamlı fark olduğu ve bu şemalarda erkeklerde daha fazla olduğu görülmektedir. Bununla beraber Kusurluluk / Utanma, Kuşkuculuk ve Kötüye Kullanılma, Terk Edilme ve Tutarsızlık, Bağımlılık / Yetersizlik, Karamsarlık ve Cezalandırıcılık şema alanlarında cinsiyetler arasında istatistiksel olarak önemli bir fark bulunamamıştır ( $\mathrm{p}>$.05).

Tablo 5. Ortaokul Öğrencilerinin Cinsiyetlerine Göre Erken Dönem Uyumsuz Şema Alanlarına İlişkin Puan Ortalamaları ve T- Testi Sonuçları

\begin{tabular}{|c|c|c|c|c|c|c|}
\hline Boyutlar & Cinsiyet & $\mathrm{N}$ & $\bar{x}$ & Ss & $\mathrm{T}$ & $\mathrm{P}$ \\
\hline \multirow{2}{*}{ ÇEŞÖT Genel } & Kadın & 928 & 2.22 & .64 & \multirow{2}{*}{-2.54} & \multirow{2}{*}{$.01^{*}$} \\
\hline & Erkek & 701 & 2.31 & .68 & & \\
\hline \multirow{2}{*}{ 1)Kopukluk Reddilmişlik } & Kadın & 928 & 2.19 & .74 & \multirow{2}{*}{-1.01} & \multirow{2}{*}{.31} \\
\hline & Erkek & 701 & 2.23 & .76 & & \\
\hline \multirow{2}{*}{ Kusurluluk / Utanma Şeması } & Kadın & 928 & 2.19 & .84 & \multirow{2}{*}{-1.21} & \multirow{2}{*}{.23} \\
\hline & Erkek & 701 & 2.24 & .85 & & \\
\hline \multirow{2}{*}{$\begin{array}{l}\text { Kuşkuculuk ve Kötüye Kullanılma Şe- } \\
\text { ması }\end{array}$} & Kadın & 928 & 2.29 & .92 & \multirow{2}{*}{-.66} & \multirow{2}{*}{.51} \\
\hline & Erkek & 701 & 2.31 & .88 & & \\
\hline \multirow{2}{*}{ Duygusal Yoksunluk Şeması } & Kadın & 928 & 1.98 & .84 & \multirow{2}{*}{-2.22} & \multirow{2}{*}{$.03^{*}$} \\
\hline & Erkek & 701 & 2.07 & .89 & & \\
\hline \multirow{2}{*}{ Terk Edilme ve Tutarsızlık Şeması } & Kadın & 928 & 2.31 & .95 & \multirow{2}{*}{.47} & \multirow{2}{*}{.64} \\
\hline & Erkek & 701 & 2.29 & .94 & & \\
\hline \multirow{2}{*}{ 2)Zedelenmişlik Özerklik ve Performans } & Kadın & 928 & 2.55 & .72 & \multirow{2}{*}{2.17} & \multirow{2}{*}{$.03^{*}$} \\
\hline & Erkek & 701 & 2.47 & .70 & & \\
\hline \multirow{2}{*}{ Başarısızlık Şeması } & Kadın & 928 & 2.06 & .85 & \multirow{2}{*}{-2.35} & \multirow{2}{*}{$.02^{*}$} \\
\hline & Erkek & 701 & 2.16 & .88 & & \\
\hline \multirow{2}{*}{ Bağımlılık / Yetersizlik Şeması } & Kadın & 928 & 2.09 & .82 & \multirow{2}{*}{-.71} & \multirow{2}{*}{.48} \\
\hline & Erkek & 701 & 2.12 & .84 & & \\
\hline \multirow{2}{*}{$\begin{array}{l}\text { Yapışıklık ve Gelişmemiş Benlik } \\
\text { Şeması }\end{array}$} & Kadın & 928 & 3.18 & 1.26 & \multirow{2}{*}{3.84} & $00 *$ \\
\hline & Erkek & 701 & 2.97 & 1.09 & & $.00^{*}$ \\
\hline Hastalık ve Tehditlere Karşı & Kadın & 928 & 2.85 & 1.30 & 412 & $00 *$ \\
\hline Dayanıksızlık Şeması & Erkek & 701 & 2.62 & 1.06 & 4.13 & $.00^{*}$ \\
\hline & Kadın & 928 & 2.13 & .73 & & \\
\hline 3)Zedelenmiş Sınırlar & Erkek & 701 & 2.34 & .75 & -5.62 & $.00^{*}$ \\
\hline Haklılık / Büyüklenmecilik Şeması & Kadın & 928 & 2.09 & .74 & 507 & $00 *$ \\
\hline & Erkek & 701 & 2.28 & .77 & -5.07 & $.00^{\circ}$ \\
\hline & Kadın & 928 & 2.18 & .90 & -508 & \\
\hline Yetersiz Ozdenetim Şeması & Erkek & 701 & 2.40 & .96 & -5.08 & $.00^{*}$ \\
\hline 4)Baskalarına Yönelimlilik & Kadın & 928 & 2.18 & .71 & 566 & $00 *$ \\
\hline 4) Бaşkalarına Yonelımılı1k & Erkek & 701 & 2.40 & .74 & -5.66 & $.00^{\circ}$ \\
\hline & Kadın & 928 & 1.90 & .86 & -387 & $00 *$ \\
\hline Kendini Onaylamama Şeması & Erkek & 701 & 2.07 & .92 & -3.87 & $.00^{*}$ \\
\hline Boyun Eğicilik Şeması & Kadın & 928 & 2.08 & .78 & -4.38 & $.00^{*}$ \\
\hline
\end{tabular}




\begin{tabular}{|c|c|c|c|c|c|c|}
\hline & Erkek & 701 & 2.26 & .84 & & \\
\hline \multirow{2}{*}{ Onay Arayıcılık Şeması } & Kadın & 928 & 2.57 & 1.00 & \multirow{2}{*}{-5.38} & \multirow{2}{*}{$.00^{*}$} \\
\hline & Erkek & 701 & 2.84 & .98 & & \\
\hline \multirow{2}{*}{ 5)Aşırı Tetikte Olma Baskılama / Ketleme } & Kadın & 928 & 2.40 & .82 & \multirow{2}{*}{-.18} & \multirow{2}{*}{.85} \\
\hline & Erkek & 701 & 2.42 & .79 & & \\
\hline \multirow{2}{*}{ Karasızlık Şeması } & Kadın & 928 & 2.50 & 1.00 & \multirow{2}{*}{1.36} & \multirow{2}{*}{.17} \\
\hline & Erkek & 701 & 2.44 & .92 & & \\
\hline \multirow{2}{*}{ Cezalandırılıcık Şeması } & Kadın & 928 & 2.31 & .85 & \multirow{2}{*}{-1.93} & \multirow{2}{*}{.05} \\
\hline & Erkek & 701 & 2.39 & .83 & & \\
\hline
\end{tabular}

${ }^{*} p<.05$

Elde edilen sonuçlar özetlenecek olursa uyumsuz şemalardan Yapışıklık ve Gelişmemiş Benlik ve Hastalık ve Tehditlere Karşı Dayanıksızlık alanlarında kadınların lehine, Duygusal Yoksunluk, Başarısızlık, Haklılık / Büyüklenmecilik, Yetersiz Özdenetim, Kendini Onaylamama, Boyun Eğicilik ve Onay Arayıcılık şema alanlarında ise erkeklerin lehine istatistiksel olarak önemli farklar bulunmuştur.

Tablo 6'ya bakıldığında EIDDÖ'ye göre genel olarak cinsiyet farkları değerlendirildiğinde cinsiyete göre anlamlı bir farklılık olmadığı görülmektedir $\left[t_{(1627)}=.22, p<.05\right]$. Fakat ölçeğin alt boyutlarında yer alan İçsel İşlevsel duygu düzenleme yöntemi $\left[t_{(1627)}=3.25, \mathrm{p}<.05\right]$ ve Dişsal İşlevsel duygu düzenleme yöntemine $\left[t_{(1627)}=2.71, \mathrm{p}<.05\right]$ cinsiyet açısından bakıldığında anlamlı bir fark olduğu ve bu yöntemlerin erkeklerde daha fazla olduğu görülmektedir.

Tablo 6. Ortaokul Öğrencilerinin Cinsiyetlerine Göre Duygu Düzenleme Yöntemlerine İlişkin Puan Ortalamaları ve T- Testi Sonuçları

\begin{tabular}{|c|c|c|c|c|c|c|c|}
\hline Boyutlar & Cinsiyet & $\mathrm{N}$ & $\bar{x}$ & Ss & $\mathrm{Sd}$ & $\mathrm{T}$ & $\mathrm{P}$ \\
\hline \multirow[t]{2}{*}{ EİDDO Genel } & Kadın & 928 & 2.67 & .46 & 1627 & .22 & .82 \\
\hline & Erkek & 701 & 2.66 & .48 & & & \\
\hline \multirow[t]{2}{*}{ İçsel İşlevsel } & Kadın & 928 & 3.92 & .79 & 1627 & 3.25 & $.00^{*}$ \\
\hline & Erkek & 701 & 3.79 & .77 & & & \\
\hline \multirow[t]{2}{*}{ İçsel İşlevsel Olmayan } & Kadın & 928 & 2.36 & .87 & 1627 & .35 & .73 \\
\hline & Erkek & 701 & 2.34 & .85 & & & \\
\hline \multirow[t]{2}{*}{ Dışsal İşlevsel } & Kadın & 928 & 3.02 & .91 & 1627 & 2.71 & $.01^{*}$ \\
\hline & Erkek & 701 & 2.90 & .87 & & & \\
\hline \multirow[t]{2}{*}{ Dışsal İşlevsel Olmayan } & Kadın & 928 & 1.68 & .73 & 1627 & -5.16 & $.00^{*}$ \\
\hline & Erkek & 701 & 1.87 & .78 & & & \\
\hline
\end{tabular}

Dışsal İşlevsel Olmayan Duygu Düzenleme yönteminde cinsiyete göre anlamlı bir fark olduğu fakat kadınlarda daha fazla olduğu görülmektedir 
$\left[t_{(1627)}=-5.16, p<.05\right]$. Ayrıca İçsel İşlevsel Olmayan alt boyutta ise cinsiyete göre anlamlı fark olmadığı görülmektedir ( $\mathrm{p}>.05)$.

Öğrencilerin Erken Dönem Uyumsuz Şema Puanlarının Anne ve Baba Ĕ̆itim Düzeyi Açısından Karşılaştırılması

Analizler için tek yönlü varyans analizi (OneWay ANOVA) testi kullanılmıştır. Tablo 7'ye göre öğrencilerin uyumsuz şema alanlarında anne eğitim durumuna göre istatistiksel olarak anlamlı farklar bulunmuştur. Kusurluluk / Utanma şemasında $[F(3,1626)=12.77, \mathrm{p}<.05]$ Onay Arayıc1lik $[F(3,1626)=7.07, \mathrm{p}<.05]$ şemasında ve Cezalandırıcılık $[F(3,1626)=12.42 \mathrm{p}<.05]$ uyumsuz şemasında annesi okuryazar/ ilkokul mezunu olan öğrencilerin annesi lise ya da yüksekokul/ fakülte/ lisansüstü mezunu olan öğrencilere göre, ortaokul mezunu olanların ve lise mezunu olanların anneleri yüksekokul/ fakülte/ lisansüstü mezun olan öğrencilere göre daha fazla puan aldıkları görülmüştür. Kuşkuculuk ve Kötüye Kullanılma şemasında [ $F(3$, $\left.{ }_{1626}=5.65, \mathrm{p}<.05\right]$, Terk Edilme ve Tutarsizlık şemasında $[F(3,1626)=5.66$, $\mathrm{p}<.05]$ ve Karamsarlık $[F(3,1626)=4.93, \mathrm{p}<.05]$ şemasında annesi okuryazar/ ilkokul mezunu olan öğrencilerin annesi lise ya da yüksekokul/ fakülte/ lisansüstü mezunu olan öğrencilere göre, ortaokul mezunu olanların ise lise mezunu olanlara göre daha fazla puan aldıkları görülmüştür. 
Tablo 7. Ortaokul Öğrencilerinin Anne Eğitim Dïzeyine Göre Erken Dönem Uyumsuz ŞemaPuan Ortalamaları ve OneWay ANOVA Sonuçlar

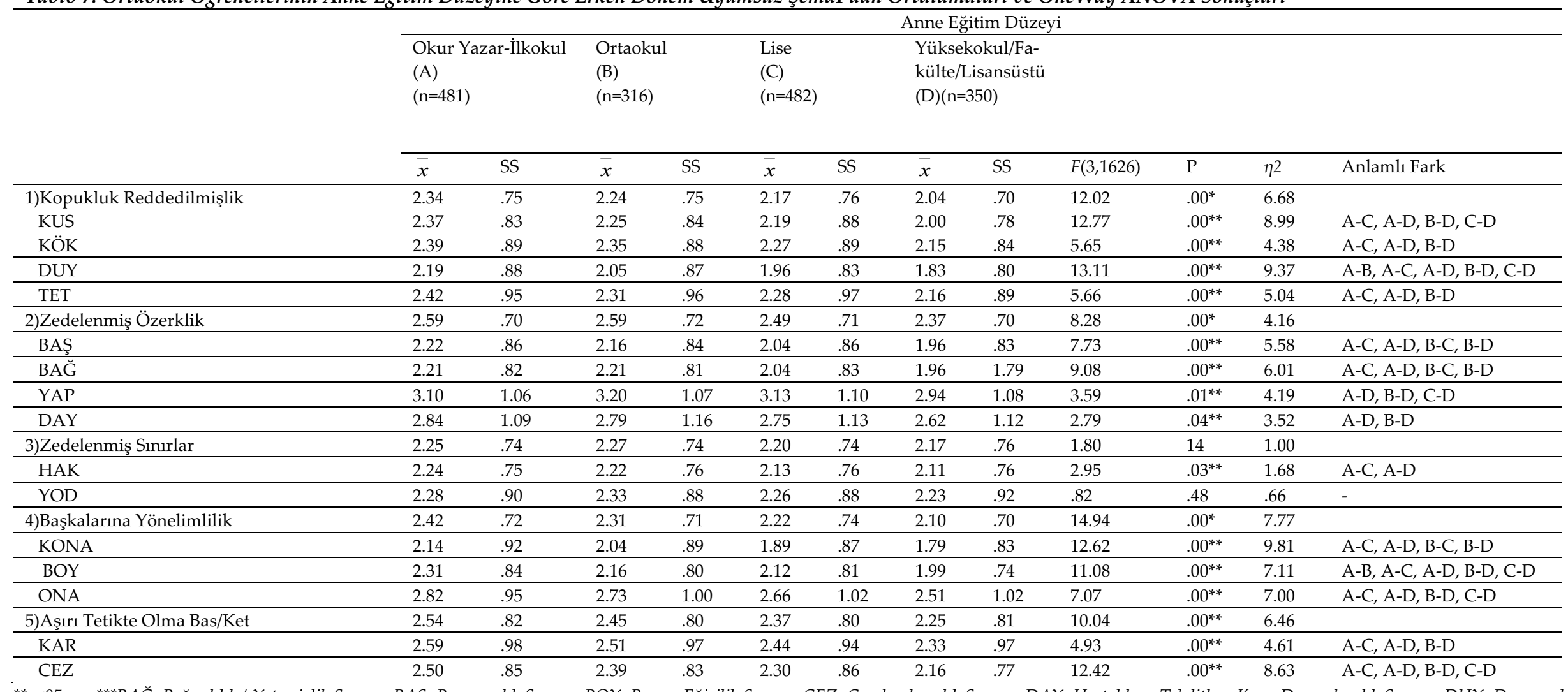

**p<05 ***BAĞ: Bağımlılık / Yetersizlik Şeması, BAŞ: Başarısızlık Şeması, BOY: Boyun Ĕ̆gicilik Şeması, CEZ: Cezalandırıcılık Şeması, DAY: Hastalık ve Tehditlere Karşı Dayanıksızlık Şeması, DUY: Duygusal Yoksunluk Şeması, HAK: Haklılı / Büyüklenmecilik Şeması, KAR: Karamsarlık Şeması, KONA: Kendini Onaylamama Şeması, KÖK: Kuşkuculuk ve Kötüye Kullanılma Şeması, KUS: Kusurluluk / Utanma Şeması, ONA: Onay Arayıcılık Şeması, TET: Terk Edilme ve Tutarsızlık Şeması, YAP: Yapışıklık ve Gelişmemiş Benlik Şeması, YÖD: Yetersiz Özdenetim Şeması 
Duygusal Yoksunluk şemasında $[F(3,1626)=13.11, \mathrm{p}<.05]$ ve Boyun Eğicilik $\left[F_{(3,1626)}=11.08, \mathrm{p}<.05\right]$ şemasında öğrencilerin annelerinden okuryazar/ilkokul mezunu olanların diğerlerine göre daha fazla puan aldıkları görülmüştür. Ayrıca annesi ortaokul ve lise mezunu olan öğrencilerin annesi yüksekokul/ fakülte/ lisansüstü mezunu olan öğrencilere göre daha fazla puan aldıkları görülmüştür. Başarısızlık $[F(3,1626)=7.77$, $\mathrm{p}<.05]$ şemasinda, Bağımlılık / Yetersizlik $[F(3,1626)=9.08, \mathrm{p}<.05]$ şemasında ve Kendini Onaylamama şemasında $[F(3,1626)=12.62, \mathrm{p}<.05]$ annesi lise ya da yüksekokul/ fakülte/ lisansüstü mezunu olan öğrencilerin, annesi okuryazar/ ilkokul mezunu öğrencilere göre daha az puan aldıkları görülmüştür.

Bir diğer alt boyut olan Yapışıklık ve Gelişmemiş Benlik $[F(3,1626)=3.59$, $\mathrm{p}<.05]$ şemasında öğrencilerden annesinin eğitim düzeyi yüksekokul/ fakülte/ lisansüstü mezunu olan öğrencilerin; annesi okuryazar/ ilkokul, ortaokul ya da lise mezunu olan öğrencilere göre daha az puan aldıkları görülmüştür. Hastalık ve Tehditlere Karşı Dayanıksızlık $\left[F_{(3,1626)}=2.79\right.$, $\mathrm{p}<.05]$ şemasında annesinin eğitim düzeyi yüksekokul/ fakülte/ lisansüstü mezunu olan öğrencilerin; annesi okuryazar/ ilkokul ya da ortaokul mezunu öğrencilere göre daha az puan aldıkları görülmüştür. Son olarak anlamlı fark bulunan Haklılık / Büyüklenmecilik $[F(3,1626)=2.95, \mathrm{p}<.05]$ şemasında öğrencilerden annesinin eğitim düzeyi okuryazar/ ilkokul olanların, annesi lise ya da yüksekokul/ fakülte/ lisansüstü mezunu olanlara göre daha fazla puan aldıkları elde edilen bulgular arasındadır.

Genel olarak bu tablodan elde edilen sonuçlar değerlendirildiğinde manidar bir şekilde anlamlı fark bulunmuş, öğrencilerin annelerinin eğitim seviyesi arttıkça uyumsuz şemalardan aldıkları puanlar düşüklük göstermiştir. 
Tablo 8. Ortaokul Öğrencilerinin Baba Eğitim Düzeyine Göre Erken Dönem Uyumsuz Şema Puan Ortalamaları ve One Way ANOVA Sonuçlar

\begin{tabular}{|c|c|c|c|c|c|c|c|c|c|c|c|c|}
\hline & \multicolumn{12}{|c|}{ Baba Eğitim Düzeyi } \\
\hline & \multicolumn{2}{|c|}{$\begin{array}{l}\text { Okur-Ya- } \\
\text { zar/Ilkokul } \\
(\mathrm{A}) \\
(\mathrm{n}=306) \\
\end{array}$} & \multicolumn{2}{|c|}{$\begin{array}{l}\text { Ortaokul } \\
\text { (B) } \\
(\mathrm{n}=323)\end{array}$} & \multicolumn{2}{|c|}{$\begin{array}{l}\text { Lise } \\
(\mathrm{C}) \\
(\mathrm{n}=495)\end{array}$} & \multicolumn{2}{|c|}{$\begin{array}{l}\text { Yüksekokul /Fa- } \\
\text { külte/Lisansüstü } \\
(\mathrm{D}) \\
(\mathrm{n}=505)\end{array}$} & \multirow[b]{2}{*}{$F(, 1626)$} & \multirow[b]{2}{*}{$\mathrm{P}$} & \multirow[b]{2}{*}{$\eta 2$} & \multirow[b]{2}{*}{ Anlamlı Fark } \\
\hline & $\bar{x}$ & SS & $\bar{x}$ & SS & $\bar{x}$ & SS & $\bar{x}$ & SS & & & & \\
\hline 1)Kopukluk Reddedilmişlik & 2.34 & .76 & 2.26 & .73 & 2.21 & .75 & 2.09 & .74 & 7.68 & $.00^{* *}$ & 4.30 & \\
\hline KUS & 2.36 & .83 & 2.31 & .82 & 2.20 & .86 & 2.08 & .84 & 9.22 & $.00^{* *}$ & 6.53 & A-C, A-D, B-C, B-D \\
\hline KÖK & 2.40 & .87 & 2.31 & .86 & 2.29 & .90 & 2.22 & .88 & 2.72 & $.04^{* *}$ & 2.12 & A-D \\
\hline DUY & 2.20 & .90 & 2.08 & .85 & 2.00 & .84 & 1.88 & .81 & 10.04 & $.00^{* *}$ & 7.26 & A-C, A-D, B-D, C-D \\
\hline TET & 2.39 & .94 & 2.34 & .97 & 2.33 & .94 & 2.19 & .94 & 3.39 & $.02^{* *}$ & 3.03 & A-D, B-D, C-D \\
\hline 2)Zedelenmiş Özerklik & 2.63 & .70 & 2.54 & .69 & 2.53 & .71 & 2.41 & .73 & 6.21 & $.00^{* *}$ & 3.13 & \\
\hline BAŞ & 2.25 & .87 & 2.11 & .81 & 2.08 & .84 & 2.02 & .88 & 4.63 & $.00^{* *}$ & 3.36 & A-B, A-C, A-D \\
\hline BAĞ & 2.25 & .81 & 2.14 & .81 & 2.12 & .81 & 1.97 & .82 & 7.85 & $.00^{* *}$ & 5.20 & A-C, A-D \\
\hline YAP & 3.15 & 1.06 & 3.16 & 1.11 & 3.12 & 1.09 & 2.98 & 1.07 & 2.56 & .05 & 2.99 & - \\
\hline DAY & 2.86 & 1.09 & 2.73 & 1.13 & 2.79 & 1.12 & 2.67 & 1.14 & 2.05 & .10 & 2.59 & - \\
\hline 3)Zedelenmiş Sınırlar & 2.31 & .76 & 2.22 & .72 & 2.26 & .75 & 2.15 & .75 & 3.05 & $.03^{* *}$ & 3.05 & \\
\hline HAK & 2.28 & .76 & 2.22 & .74 & 2.18 & .76 & 2.08 & .75 & 4.96 & $.00^{* *}$ & 2.82 & A-D, B-D, C-D \\
\hline YOD & 2.34 & .90 & 2.21 & .87 & 2.31 & .88 & 2.23 & .92 & 1.89 & .13 & 1.51 & - \\
\hline 4)Başkalarına Yönelimlilik & 2.45 & .74 & 2.32 & .71 & 2.27 & .71 & 2.13 & .72 & 13.22 & $.00^{* *}$ & 13.22 & \\
\hline KONA & 2.13 & .93 & 2.08 & .93 & 1.95 & .87 & 1.83 & .84 & 9.09 & $.00^{* *}$ & 7.11 & A-C, A-D, B-C, B-D, C-D \\
\hline BOY & 2.33 & .86 & 2.17 & .79 & 2.17 & .82 & 2.03 & .75 & 9.24 & $.00^{* *}$ & 5.95 & A-B, A-C, A-D, B-D, C-D \\
\hline ONA & 2.89 & .98 & 2.72 & .96 & 2.70 & .99 & 2.53 & 1.03 & 8.56 & $.00^{* *}$ & 8.46 & A-B, A-C, A-D, B-D, C-D \\
\hline 5)Aşırı Tetikte Olma Bas/ Ket & 2.57 & .83 & 2.42 & .78 & 2.39 & .80 & 2.33 & .81 & 5.88 & $.00^{* *}$ & 5.88 & \\
\hline KAR & 2.63 & .99 & 2.49 & .92 & 2.44 & .95 & 2.41 & .99 & 3.65 & $.01^{* *}$ & 3.42 & A-C, A-D \\
\hline CEZ & 2.50 & .88 & 2.36 & .83 & 2.35 & .85 & 2.34 & .81 & 6.43 & $.00^{* *}$ & 4.52 & A-B, A-C, A-D, B-D, C-D \\
\hline
\end{tabular}

114 • OPUS ๑ U/uslararası Toplum Araştrmaları Dergisi 
Tablo 8'e bakıldığında Kusurluluk / Utanma $[F(3,1626)=9.22, \mathrm{p}<.05]$ uyumsuz şemasında ve Kendini Onaylamama $[F(3,1626)=9.09, \mathrm{p}<.05]$ uyumsuz şemasında öğrencilerden babası okuryazar/ ilkokul mezunu ya da ortaokul mezunu olanlar, babası lise ya da yüksekokul/ fakülte/ lisansüstü mezun olan öğrencilere göre daha fazla puan aldıkları görülmüştür. Ayrıca babası lise mezunu olanlar da babası yüksekokul/ fakülte/ lisansüstü mezun olan öğrencilere göre daha fazla puan almışlardır. Duygusal Yoksunluk $[F(3,1626)=10.09, \mathrm{p}<.05]$ uyumsuz şemasında ve Bağımlılık / Yetersizlik $[F(3,1626)=7.85, \mathrm{p}<.05]$ şemasında babası lise ya da yüksekokul/ fakülte/ lisansüstü mezun olan öğrencilerin, babası okuryazar/ ilkokul mezunu olanlara göre; babası yüksekokul/ fakülte/ lisansüstü mezun olan öğrencilerin, babası ortaokul ya da lise mezunu olanlara göre daha az puan aldıkları görülmüştür. Kuşkuculuk ve Kötüye Kullanılma şemasinda $[F(3,1626)=2.72, \mathrm{p}<.05]$ babası okuryazar/ ilkokul mezunu olanların babası yüksekokul/ fakülte/ lisansüstü mezun olanlara göre daha fazla puan aldıkları görülmüştür.

Terk Edilme ve Tutarsızlık şemasında $[F(3,1626)=3.39, \mathrm{p}<.05]$ ve Haklılık / Büyüklenmecilik $[F(3,1626)=4.96, \mathrm{p}<.05]$ şemasında öğrencilerden babası yüksekokul/ fakülte/ lisansüstü mezunu olanların babası okuryazar/ ilkokul, ortaokul ya da lise mezunu olanlara göre daha az puan aldıkları görülmüştür. Başarısızlık $[F(3,1626)=4.63, \mathrm{p}<.05]$ şemasında babası okuryazar/ ilkokul mezunu olanların, babası ortaokul, lise ya da yüksekokul/ fakülte/ lisansüstü mezunu olanlara göre daha fazla puan aldığ gular arasindadır.

Boyun Eğicilik $[F(3,1626)=9.24, \mathrm{p}<.05]$ şemasında, Onay Arayıcılık $[F(3$, $\left.{ }_{1626)}=8.56, \mathrm{p}<.05\right]$ şemasında ve Cezalandırıcilık $\left[F_{(3,1626)}=6.43 \mathrm{p}<.05\right]$ şemasında babası okuryazar/ilkokul mezunu olanların, babası ortaokul, lise ya da yüksekokul/ fakülte/ lisansüstü mezunu olanlara göre daha fazla puan aldığı; babası yüksekokul/ fakülte/ lisansüstü mezun olan öğrencilerin, babası ortaokul ya da lise mezunu olanlara göre daha az puan aldıkları görülmüştür. Son olarak Karamsarlık $[F(3,1626)=3.65$, p $<.05]$ şemasında babası okuryazar/ ilkokul mezunu olanların babası lise ya da yüksekokul/ fakülte/ lisansüstü mezunu olanlara göre daha fazla puan aldığı görülmüştür. Genel olarak tablo değerlendirildiğinde baba eğitim düzeyi yüksek olanlar daha düşük eğitim düzeyine sahip olanlara göre daha az puan almışlardır. 


\section{Öğrencilerin Duygu Yöntemleri Puanlarının Anne ve Baba Ĕ̆itim Düzeyin Açısından Karşılaştırılması}

Analizler için tek yönlü varyans analizi OneWay ANOVA testi kullanılmiştır.

Tablo 9. Ortaokul Öğrencilerinin Anne Eğitim Düzeyine Göre Duygu Düzenleme Yöntemlerine İlişkin Puan Ortalamaları ve OneWay ANOVA Sonuçlarn

\begin{tabular}{|c|c|c|c|c|c|c|c|c|c|c|c|c|}
\hline \multicolumn{13}{|c|}{ Anne Eğitim Düzeyi } \\
\hline & \multicolumn{2}{|c|}{$\begin{array}{l}\text { Okur-Ya- } \\
\text { zar/ } \\
\text { İlkokul } \\
(\mathrm{A}) \\
(\mathrm{n}=481) \\
\end{array}$} & \multicolumn{2}{|c|}{$\begin{array}{l}\text { Ortaokul } \\
(\mathrm{B}) \\
(\mathrm{n}=316)\end{array}$} & \multicolumn{2}{|c|}{$\begin{array}{l}\text { Lise } \\
(\mathrm{C}) \\
(\mathrm{n}=482)\end{array}$} & \multicolumn{2}{|c|}{$\begin{array}{l}\text { Yüksekokul/ } \\
\text { Fakülte/ } \\
\text { Lisansüstü } \\
(\mathrm{D}) \\
(\mathrm{n}=350)\end{array}$} & & & & \\
\hline & $\bar{x}$ & SS & $\bar{x}$ & SS & $\bar{x}$ & SS & $\bar{x}$ & SS & $F(3,1626)$ & $\mathrm{P}$ & $\eta^{2}$ & $\begin{array}{l}\text { An- } \\
\text { lamlı } \\
\text { Fark }\end{array}$ \\
\hline İçsel İ. & 3.79 & .81 & 3.76 & .76 & 3.90 & .77 & 4.00 & .74 & 6.88 & $.00^{* *}$ & 4.16 & $\begin{array}{l}\text { AC, } \\
\text { A-D, } \\
\text { B-C, } \\
\text { B-D }\end{array}$ \\
\hline İçsel İ. O. & 2.41 & .90 & 2.40 & .82 & 2.29 & .84 & 2.30 & .88 & 2.22 & .08 & 1.65 & \\
\hline Dışsal İ. & 2.93 & .90 & 2.96 & .88 & 2.99 & .90 & 2.99 & .89 & .39 & .76 & .31 & \\
\hline Dişsal İ. O. & 1.77 & .75 & 1.78 & .77 & 1.74 & .75 & 1.78 & .76 & .26 & .85 & .15 & \\
\hline
\end{tabular}

Tablo 9'a göre, öğrencilerin anne eğitim düzeyinde göre duygu düzenleme yöntemlerinden içsel işlevsel duygu düzenleme yönteminde $[F(3,1626)$ $=6.88, \mathrm{p}<.05]$ anlamlı fark çıkmıştır. İçsel işlevsel duygu düzenleme yönteminde öğrencilerden anneleri okuryazar/ ilkokul mezunu ya da ortaokul mezunu olanların, babası lise ya da yüksekokul/ fakülte/ lisansüstü mezun olan öğrencilere göre daha az puan aldıkları görülmüştür. 
Tablo 10. Ortaokul Öğrencilerinin Baba Eğitim Düzeyine Göre Duygu Düzenleme Yöntemlerine İlişkin Puan Ortalamaları ve OneWay ANOVA Sonuçları

\begin{tabular}{|c|c|c|c|c|c|c|c|c|c|}
\hline \multicolumn{10}{|c|}{ Baba Eğitim Düzeyi } \\
\hline & $\begin{array}{l}\text { Okur- } \\
\text { Yazar/ } \\
\text { İlkokul } \\
(\mathrm{A}) \\
(\mathrm{n}=306)\end{array}$ & $\begin{array}{l}\text { Ortaokul } \\
(B) \\
(n=323)\end{array}$ & $\begin{array}{l}\text { Lise } \\
(\mathrm{C}) \\
(\mathrm{n}=495)\end{array}$ & $\begin{array}{c}\text { Yük } \\
\text { Faki } \\
\text { Lisa } \\
(\mathrm{D}) \\
(\mathrm{n}=5\end{array}$ & & & & & \\
\hline & $\bar{x} \quad$ SS & SS & SS & $\bar{x}$ & SS & $F(3,1625)$ & $\mathrm{P}$ & $\eta^{2}$ & $\begin{array}{l}\text { An- } \\
\text { lamlı } \\
\text { Fark }\end{array}$ \\
\hline İçsel İ. & $3.76 \quad .83$ & $3.74 \quad .79$ & $3.85 \quad .76$ & 4.00 & .74 & 10.25 & $.00^{* *}$ & 6.14 & $\begin{array}{l}\text { A-D, } \\
\text { B-D, } \\
\text { C-D }\end{array}$ \\
\hline $\begin{array}{l}\text { İçsel } \\
\text { İ. O. }\end{array}$ & $2.36 \quad .88$ & $2.36 \quad .82$ & $2.34 \quad .85$ & 2.35 & .90 & .07 & .97 & .06 & \\
\hline Dışsal İ. & $2.90 \quad .89$ & $2.90 \quad .86$ & $3.07 \quad .92$ & 2.94 & .89 & 3.47 & $.02^{* *}$ & 2.77 & $\begin{array}{l}\text { A-C, } \\
\text { B-C, } \\
\text { C-D }\end{array}$ \\
\hline $\begin{array}{l}\text { Dişsal } \\
\text { İ. O. }\end{array}$ & $\begin{array}{ll}1.75 & .75\end{array}$ & $1.82 \quad .76$ & $1.74 \quad .73$ & 1.76 & .78 & .83 & .48 & 47 & \\
\hline
\end{tabular}

Tablo 10 incelendiğinde, öğrencilerin baba eğitim göre duygu düzenleme yöntemlerinden içsel işlevsel duygu düzenleme yöntemi $[F(3,1626)$ $=10.25, \mathrm{p}<.05]$ ve dişsal işlevsel duygu düzenleme yönteminde $[F(3,1626)=$ $3.47, \mathrm{p}<.05]$ anlamlı fark çıkmıştır. İçsel işlevsel duygu düzenleme yönteminde öğrencilerden babaları fakülte / yüksekokul / lisansüstü mezunu olanlar; babaları, okuryazar / ilkokul, ortaokul ya da lise mezunu olanlara göre daha fazla puan almışlardır. Dışsal işlevsel duygu düzenleme yönteminde babası lise mezunu olanlar; babası, okuryazar / ilkokul mezunu, ortaokul mezunu göre daha fazla puan almışlardır. Ayrıca babaları fakülte / yüksekokul / lisansüstü mezunu olanlar; babaları lise mezunu olanlara göre daha az puan almışlardır. Son olarak elde edilen bulgu içsel işlevsel olmayan ve dişsal işlevsel olmayan duygu düzenleme türlerinde ise baba eğitim düzeyine göre anlamlı bir fark olmadığı görülmüştür ( $>$ >.05). 


\section{Öğrencilerin Erken Dönem Uyumsuz Şemalarn İle Duygu Düzenleme Yön- temleri Arasında Anlamlı İlişki Olup Olmadığının Belirlenmesi}

Öğrencilerin erken dönem uyumsuz şemalar ile duygu düzenleme yöntemleri arasında anlamlı farklılaşma olup olmadığını belirlemek için Pearson momentler çarpım korelasyon tekniği kullanılmıştır.

Tablo 11.Ortaokul Öğrencilerinde Erken Dönem Uyumsuz Şemalar İle Duygu Düzenleme Ölçeğinin Alt Boyutları Arasındaki İlişkiye Dair Bulgular

\begin{tabular}{|c|c|c|c|c|}
\hline & $\begin{array}{l}\text { İçsel } \\
\text { İşlevsel }\end{array}$ & $\begin{array}{l}\text { İçsel İşlevsel } \\
\text { Olmayan }\end{array}$ & $\begin{array}{l}\text { Dişsal } \\
\text { İşlevsel }\end{array}$ & $\begin{array}{l}\text { Dişsal İşlevsel } \\
\text { Olmayan }\end{array}$ \\
\hline KUS & $-.14^{* *}$ & $.45^{* *}$ & $-.05^{*}$ & $.23^{* *}$ \\
\hline KÖK & $.10^{* *}$ & $.49^{* *}$ & .02 & $.28^{* *}$ \\
\hline DUY & $-.15^{* *}$ & $.48^{* *}$ & -.04 & $.27^{* *}$ \\
\hline TET & $-.08^{* *}$ & $.41^{* *}$ & $.06^{*}$ & $.22^{* *}$ \\
\hline BAŞ & $-.20^{* *}$ & $.44^{* *}$ & -.03 & $.24^{* *}$ \\
\hline BAĞ & -.15 & $.38^{* *}$ & $.09^{* *}$ & $.22^{* *}$ \\
\hline YAP & $.06^{* *}$ & $.09 * *$ & $.15^{* *}$ & -.38 \\
\hline DAY & .00 & $.41^{* *}$ & $.12^{* *}$ & $.19^{* *}$ \\
\hline HAK & $-.23^{* *}$ & $.41^{* *}$ & .01 & $.43^{* *}$ \\
\hline YÖD & $-.28^{* *}$ & $.39^{* *}$ & $-.05^{*}$ & $.39^{* *}$ \\
\hline KONA & -.17 & $.44^{* *}$ & -.04 & $.26^{* *}$ \\
\hline BOY & $-.07^{* *}$ & $.34^{* *}$ & .02 & $.11^{* *}$ \\
\hline ONA & .02 & $.28^{* *}$ & $.13^{* *}$ & $.07^{* *}$ \\
\hline KAR & -.16 & $.56^{* *}$ & -.01 & $.32^{* *}$ \\
\hline CEZ & $.08^{* *}$ & $.39^{* *}$ & .02 & $.21^{* *}$ \\
\hline \multicolumn{5}{|c|}{ 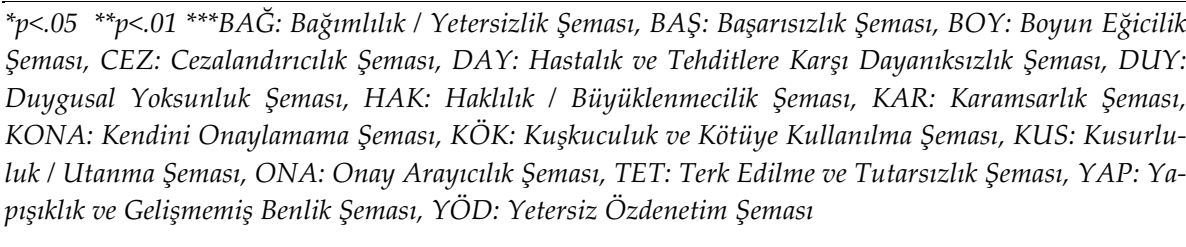 } \\
\hline
\end{tabular}

Tablo 11'e göre içsel işlevsel duygu düzenleme yöntemi ile Şema Ölçeğinin uyumsuz şema alanları ile arasındaki anlamlı ilişki düzeyi şu şekildedir: Kusurluluk / utanma $(r=-.14, \mathrm{p}<.01)$, duygusal yoksunluk $(r=-.15$, $\mathrm{p}<.01)$, terk edilme ve tutarsizlık $(r=-.08, \mathrm{p}<.01)$, başarısızlık $(r=-.20$, $\mathrm{p}<.01)$, hakl1lık / büyüklenmecilik $(r=-.23, \mathrm{p}<.01)$, yetersiz özdenetim $(r=-$ $.28, \mathrm{p}<.01)$, boyun eğicilik $(r=-.07, \mathrm{p}<.01)$ şemaları ile düşük düzeyde, negatif yönlü; kuşkuculuk ve kötüye kullanılma $(r=.10$, $\mathrm{p}<.01)$, yapışıklık ve gelişmemiş benlik $(r=.06, \mathrm{p}<.01)$ vecezalandırıcılık $(r=.08, \mathrm{p}<.01)$ şema 
alanları arasında düşük düzeyde, pozitif yönlü anlamlı ilişki bulunmuştur. Duygu Düzenleme Ölçeğinin içsel işlevsel duygu düzenleme yöntemi ile bağımlılık / yetersizlik, hastalık ve tehditlere karşı dayanıksızlık, kendini onaylamama, onay arayıcılık ve karamsarlık uyumsuz şema alanları arasında anlamlı düzeyde bir ilişki olmadığı anlaşılmıştır ( $p>05)$.

Duygu Düzenleme Ölçeğinin içsel işlevsel olmayan duygu düzenleme yöntemi ile Şema Ölçeğinin uyumsuz şema alanları ile arasındaki anlamlı ilişki düzeyi şu şekildedir: Kusurluluk / utanma $(r=.45$, p<.01), kuşkuculuk ve kötüye kullanılma $(r=.49, \mathrm{p}<.01)$, duygusal yoksunluk $(r=.48$, $\mathrm{p}<.01)$, terk edilme ve tutarsızlık $(r=.41, \mathrm{p}<.01)$, başarısızlık $(r=.44, \mathrm{p}<.01)$ ve bağımlılık $(r=.38, \mathrm{p}<.01)$ şema alanları arasında orta düzeyde, pozitif yönlü;hastalık ve tehditlere karşı dayanıksızlık $(r=.41, \mathrm{p}<.01)$, haklılık / büyüklenmecilik $(r=.41, \mathrm{p}<.01)$, yetersiz özdenetim $(\mathrm{r}=.39, \mathrm{p}<.01)$, kendini onaylamama $(r=.44, \mathrm{p}<.01)$, boyun eğicilik $(r=.34, \mathrm{p}<.01)$, karamsarlık $(r$ $=.56, \mathrm{p}<.01)$ ve cezalandırıcılık $(r=.39, \mathrm{p}<.01)$ şema alanları arasında orta düzeyde pozitif yönlü; yapışıklık ve gelişmemiş benlik $(r=.09, \mathrm{p}<.01)$ ve onay arayıcılık $(r=.28, \mathrm{p}<.01)$,) şema alanı arasında düşük düzeyde, pozitif yönlü anlamlı ilişki bulunmuştur.

Duygu Düzenleme Ölçeğinin dişsal işlevsel duygu düzenleme yöntemi ile Şema Ölçeğinin uyumsuz şema alanları ile arasındaki anlamlı ilişki düzeyi şu şekildedir: Kusurluluk / utanma $(r=-.05$, p>05) ve yetersiz özdenetim $(r=-.05, \mathrm{p}<.01)$ şema alanı arasında düşük düzeyde, negatif yönlü; terk edilme ve tutarsızlık $(r=.06, \mathrm{p}>.05)$, bağımlılık $(r=.09, \mathrm{p}<.01)$, yapışıklık ve gelişmemiş benlik $(r=.15, \mathrm{p}<.01)$, hastalık ve tehditlere karşı dayanıksızlık $(r=.12, \mathrm{p}<.01)$ ve onay arayıcılık $(r=.13$, $\mathrm{p}<.01)$ şema alanları arasında düşük düzeyde, pozitif yönlü anlamlı ilişki bulunmuştur. İçsel işlevsel duygu düzenleme yöntemi ile kuşkuculuk ve kötüye kullanılma, duygusal yoksunluk, başarısızlık, haklılık / büyüklenmecilik, kendini onaylamama, boyun eğicilik, karamsarlık ve cezalandırıcılık şema alanları arasında anlamlı düzeyde bir ilişki olmadığı anlaşılmıştır (p>.05).

Duygu Düzenleme Ölçeğinin dişsal işlevsel olmayan duygu düzenleme yöntemi ile Şema Ölçeğinin uyumsuz şema alanları ile arasındaki anlamlı ilişki düzeyi şu şekildedir: Kusurluluk / utanma $(r=.23, \mathrm{p}<.01)$, kuşkuculuk ve kötüye kullanılma $(r=.28, \mathrm{p}<.01)$, duygusal yoksunluk $(r=$ .27 , $\mathrm{p}<.01)$, terk edilme ve tutarsızlık $(r=.22, \mathrm{p}<.01)$, başarısızlık $(r=.24$, $\mathrm{p}<.01)$, bağımlılık $(r=.22, \mathrm{p}<.01)$, hastalık ve tehditlere karşı dayanıksızlık 
$(r=.19, \mathrm{p}<.01)$, kendini onaylamama $(r=.26, \mathrm{p}<.01)$, boyun eğicilik $(r=.11$, $\mathrm{p}<.01)$, onay arayıc1lik $(\mathrm{r}=.07, \mathrm{p}<.01)$ ve cezalandirıcilik $(r=.21, \mathrm{p}<.01)$ şema alanları arasında düşük düzeyde, pozitif yönlü; haklılık / büyüklenmecilik $(r=.43, \mathrm{p}<.01)$, yetersiz özdenetim $(r=.39, \mathrm{p}<.01)$ ve karamsarlık $(r=.32, \mathrm{p}<.01)$ şema alanları arasında orta düzeyde, pozitif yönlü anlamlı ilişki bulunmuştur. Dışsal işlevsel olmayan duygu düzenleme yöntemi ile yapışıklık ve gelişmemiş benlik şema alanı arasında anlamlı düzeyde bir ilişki olmadığı anlaşılmıştır ( $\mathrm{p}>$.05).

\section{Öğrencilerin Erken Dönem Uyumsuz Şemalarının Duygu Düzenleme Yön- temlerini Yordamasına İlişkin Elde Edilen Bulgular}

Erken dönem uyumsuz şema alanlarının duygu düzenleme yöntemlerini yordama düzeyini belirlemek için doğrusal regresyon analizi stepwise tekniği kullanılmıştır. Elde edilen bulgularda tüm alanlar yordayıcı değişen olarak dahil edilse de tablolarda sadece anlamlı düzeyde yordayan alanlar aşağıda tablolar halinde verilmiştir.

Tablo 12.Şema Alanlarının İçsel İşlevsel Olmayan Duygu Düzenleme Yöntemini Yordamasına İlişkin Regresyon Analizi Bulguları

\begin{tabular}{|c|c|c|c|c|c|c|c|c|c|}
\hline Model & $\mathrm{R}^{2}$ & $\begin{array}{l}\text { Uyarlan- } \\
\text { miş } \text { R }^{2}\end{array}$ & $\mathrm{sd}$ & $\begin{array}{l}\text { Kareler } \\
\text { Toplamı }\end{array}$ & $\begin{array}{l}\text { Kareler } \\
\text { Ortalaması }\end{array}$ & $F$ & $\mathrm{p}$ & & $T$ \\
\hline \multirow[t]{2}{*}{3} & .326 & .324 & 3 & 395.501 & 131,834 & 261.68 & $0.00^{* *}$ & $\begin{array}{l}\text { Zedelen- } \\
\text { miş } \\
\text { Özerklik } \\
\text { ve Perf. }\end{array}$ & -.65 \\
\hline & & & & & & & & $\begin{array}{l}\text { Başkala- } \\
\text { rına } \\
\text { Yönelimli- } \\
\text { lik }\end{array}$ & -.58 \\
\hline
\end{tabular}

${ }^{* *} p<.01$ (sd: Serbestlik derecesi)

Tablo 12'ye göre, şema alanlarından Zedelenmiş Özerklik ve Performans şema alanının varyansın \%33'ünü açıkladığı ve içsel işlevsel olmayan duygu düzenleme yöntemini yordadığ1 $\left(F_{(2,1628)}=261.68, p<.001\right)$; Başkalarına Yönelimlilik şema alanın varyansın \%33'ünü açıkladığı ve içsel işlevsel olmayan duygu düzenleme yöntemini yordadiğ ${ }_{1}\left(F_{(2,1628)}=261.68\right.$, 
$p<.001)$ görülmüştür. Yani katılımcıların zedelenmiş özerklik ve performans, başkalarına yönelimlilik şema alanlarının puanları öğrencilerde arttıkça duygu düzenleme yöntemlerinden içsel işlevsel olmayan duygu düzenlemenin kullanımı da artmaktadır.

Tablo 13.Şema Alanlarının Dışsal İşlevsel Olmayan Duygu Düzenleme Yöntemini Yordamasına İlişkin Regresyon Analizi Bulguları

\begin{tabular}{llllllllll}
\hline Model & $\mathrm{R}^{2}$ & $\begin{array}{l}\text { Uyarlan- } \\
\text { miş } \mathrm{R}^{2}\end{array}$ & $\mathrm{sd}$ & $\begin{array}{l}\text { Kareler } \\
\text { Toplamı } 1\end{array}$ & $\begin{array}{l}\text { Kareler } \\
\text { Ortala- } \\
\text { ması }\end{array}$ & $F$ & $\mathrm{P}$ & & $\mathrm{T}$ \\
\hline 5 & .221 & .216 & 5 & 206.04 & 41.208 & 91.89 & $0.00^{* *}$ & $\begin{array}{l}\text { Kopukluk } \\
\text { Reddedil- } \\
\text { mişlik }\end{array}$ & 2.38 \\
\hline
\end{tabular}

${ }^{* *} p<.01 \quad$ (sd: Serbestlik derecesi)

Tablo 13'e göre, şema alanlarından Kopukluk ve Reddedilmişlik şema alanının varyansın \%21'sini açıkladığı ve dışsal işlevsel olmayan duygu düzenlemeyi yordadığ $\left(F_{(4,1628)}=91.89, p<.001\right)$ elde edilen bulgular arasındadır. Yani, katılımcıların Kopukluk ve Reddedilmişlik alanın öğrencilerde puanı arttıkça duygu düzenleme türünden dışsal işlevsel olmayan duygu düzenleme yönteminin kullanımı da artmaktadır.

Tablo 14.Erken Dönem Uyumsuz Şemalarn İçsel İşlevsel Olmayan Duygu Düzenleme Yöntemini Yordamasına İlişkin Regresyon Analizi Bulguları

\begin{tabular}{|c|c|c|c|c|c|c|c|c|c|}
\hline Model & $\mathrm{R}^{2}$ & $\begin{array}{l}\text { Uyarlan- } \\
\text { miş } R^{2}\end{array}$ & $\mathrm{sd}$ & $\begin{array}{l}\text { Kareler } \\
\text { Toplamı }\end{array}$ & $\begin{array}{l}\text { Kareler } \\
\text { Ortala- } \\
\text { mas1 }\end{array}$ & F & $\mathrm{p}$ & & $\mathrm{T}$ \\
\hline \multirow[t]{6}{*}{6} & .35 & .35 & 6 & 428.447 & 70.908 & 145.81 & $0.00^{* *}$ & KAR & 10.28 \\
\hline & & & & & & & & KUS & 3.97 \\
\hline & & & & & & & & DUY & 2.70 \\
\hline & & & & & & & & DAY & 3.88 \\
\hline & & & & & & & & YAP & -2.63 \\
\hline & & & & & & & & KÖK & 2.15 \\
\hline
\end{tabular}

**p<.01(sd: Serbestlik derecesi) *** DAY: Hastalık ve Tehditlere Karşı Dayanıksızlık Şeması, DUY: Duygusal Yoksunluk Şeması, KAR: Karamsarlık Şeması, KÖK: Kuşkuculuk ve Kötüye Kullanılma Şeması, KUS: Kusurluluk / Utanma Şeması, YAP: Yapışıklık ve Gelişmemiş Benlik Şeması,

Tablo 14'e göre, uyumsuz şemalardan KAR, KUS, DUY, DAY, YAP ve KÖK alanlarının varyansın \%35'ini açıkladığı ve içsel işlevsel olmayan 
duygu düzenleme yöntemini yordadığ $(F(5,1624)=145.81, p<.001)$ görülmüştür. Bu şekilde, katılımcıların bahsedilen şema puanları öğrencilerde arttıkça içsel işlevsel olmayan duygu düzenlemenin kullanımı artmaktadir.

Tablo 15.Erken Dönem Uyumsuz Şemalarnn Dışsal İşlevsel Olmayan Duygu Düzenleme Yöntemini Yordamasına İlişkin Regresyon Analizi Bulgular

\begin{tabular}{|c|c|c|c|c|c|c|c|c|c|}
\hline Model & $\mathrm{R}^{2}$ & $\begin{array}{l}\text { Uyar- } \\
\text { lanmış } \\
\mathrm{R}^{2}\end{array}$ & sd & $\begin{array}{l}\text { Kareler } \\
\text { Top- } \\
\text { lam1 }\end{array}$ & $\begin{array}{l}\text { Kareler } \\
\text { Ortala- } \\
\text { mas1 }\end{array}$ & $\mathrm{F}$ & $p$ & & $\mathrm{~T}$ \\
\hline \multirow[t]{6}{*}{6} & .23 & .23 & 6 & 219.2 & 36.533 & 82.92 & $0.00^{* *}$ & HAK & 11.11 \\
\hline & & & & & & & & YÖD & 5.29 \\
\hline & & & & & & & & BOY & -4.54 \\
\hline & & & & & & & & KAR & 4.07 \\
\hline & & & & & & & & YAP & -2.65 \\
\hline & & & & & & & & ONA & -2.42 \\
\hline
\end{tabular}

**p<.01(sd: Serbestlik derecesi) ${ }^{* * *}$ BOY: Boyun Eğicilik Şeması, HAK: Haklılık / Büyüklenmecilik Şeması, KAR: Karamsarlık Şeması, ONA: Onay Arayıcılık Şeması, YAP: Yapışıklık ve Gelişmemiş Benlik Şeması, YÖD: Yetersiz Özdenetim Şeması

Tablo-15'e göre, uyumsuz şemalardan HAK, YÖD, BOY, KAR, YAP ve ONA alanlarının varyansın \%23'ünü açıkladığı ve dışsal işlevsel olmayan duygu düzenleme yöntemini yordadığ $(F(5,1624)=82.92, p<.001)$ görülmüştür. Yani öğrencilerin bahsedilen şema puanları arttıkça içsel işlevsel olmayan duygu düzenleme yönteminin kullanımı da artmaktadır.

\section{Sonuç ve Tartışma}

Araştırma örneklemini oluşturan ortaokul öğrencilerinin duygu düzenleme türlerinden en çok içsel işlevsel duygu düzenleme yöntemini kullandıkları ve an az dışsal işlevsel duygu düzenleme yöntemini kullandıkları görülmüştür. Livingstone vd. (2009), yaptı̆̆ çalışmasında işlevsel olmayan duygu düzenleme stratejilerini daha fazla kullandığını söylemişlerdir.

Öğrencilerde en fazla aritmetik ortalamaya sahip olan uyumsuz şemalar sırasıyla YAP, DAY ve ONA olmuştur. En az aritmetik ortalamaya sahip olanlar uyumsuz şemaların ise KONA, DUY ve BAŞ olduğu görül- 
müştür. Güner (2013) yaptığı ölçek geliştirme çalışmasında bulunan sonuçlar bu bulguyu destekler niteliktedir: En fazla aritmetik ortalamaya sahip olan uyumsuz şemalar YAP, ONA ve DAY; en az aritmetik ortalamaya sahip olanlar uyumsuz şemaların ise BAŞ, DUY ve KONA olduğu görülmüştür

Araştırmanın ilk alt probleminden yola çıkılarak yapılan analizlerin sonucuna göre ÇEŞÖT genel ortalama puanlarının erkeklerde daha yüksek olduğu bulunmuştur. Akhun (2012) üniversite öğrencileriyle yaptığ 1 çalışmasında erkeklerin kadınlara göre daha yüksek puan aldığını belirtmiştir. Yanık (2015) çalışmasından erkek katılımcıların kadın katılımcılara göre kopukluk ve yüksek standartlar şema alanlarını daha fazla kullandığı bulgusunu elde etmiştir. Kevlekçi'nin (2013) yaptığı çalışmada da benzer sonuçlar elde edilmiştir. Bu sonuçlara göre yaş grupları değişse de erkeklerin genel olarak uyumsuz şemaları daha fazla bulunduğu söylenebilir. Gereksinme alanlarına göre bakıldığında zedelenmiş özerklik ve performans, zedelenmiş sınırlar ve başkalarına yönelimlilik alanlarında cinsiyete göre anlamlı farklılık olduğu bulunmuştur. Zedelenmiş özerklik ve performans alanında kız öğrencilerin, zedelenmiş sınırlar ve başkalarına yönelimlilik alanlarında ise erkek öğrencilerin daha fazla puan ortalamasına sahip olduğu görülmüştür. Uyumsuz şemalardan YAP ve DAY alanlarında kadınların, DUY, BAŞ, HAK, YÖD, KONA, BOY ve ONA şema alanlarında ise erkeklerin lehine istatistiksel olarak anlamlı farklar bulunmuştur. Boysan (2012), üniversite öğrencileriyle yaptığı çalışmasında erkeklerin kadınlara göre daha fazla kopukluk ve reddedilmişlik şemalarına sahip olduklarını tespit etmiştir. Bulgunun bu araştırmadan elde edilen bulgulardan farklı olmasının sebebi örneklem grubunun üniversite öğrencisi olması olabileceği düşünülmektedir.

Araştırma problemlerinden yola çıkılarak elde edilen bulgulara göre EIDDÖ alt boyutlarında içsel işlevsel duygu düzenleme yöntemi ve dışsal işlevsel duygu düzenleme yöntemi cinsiyet açısından anlamlı farklılık göstermiştir ve bu bulgu erkeklerin lehinedir. Dışsal işlevsel olmayan duygu düzenleme yöntemi de cinsiyet açısından anlamlı farklılık göstermektedir ve bu bulgu kadınların lehinedir.

Öğrencilerin uyumsuz şemaları anne eğitim düzeyine göre anlamlı farklar göstermiştir. Öğrencilerin annelerinin eğitim seviyesi arttıkça uyumsuz şemalardan aldıkları puanlar düşmüştür. Uyumsuz şemalara 
sahip öğrencilerin anneleri okur-yazar olmayan, ilkokul ve ortaokul eğitim düzeylerindedir. Anneleri fakülte/ yüksekokul mezunu olanlar, anneleri daha düşük eğitim düzeyine sahip olan öğrenciler göre daha az şema puanlarına sahiptir. Bu durumdan yola çıkılarak öğrencilerin daha sağlıklı bireyler olmasında anne eğitim düzeyinin büyük bir etkisi olduğu söylenebilir. Boysan (2012), yaptığı çalışmasında ebeveynlerin eğitim düzeyine göre uyum bozucu şema alanlarında manidar bir farka rastlamamiştır.

Elde edilen bir diğer bulgu baba eğitim düzeyine göre uyumsuz şemalar arasında anlamlı farklar bulunmuştur. Öğrencilerin babalarının eğitim seviyesi arttıkça uyumsuz şemalardan aldıkları puanlar düşmüştür. Uyumsuz şemalara sahip öğrenciler arasında en fazla anlamlı fark babaları ilkokul mezunu olanlar ile fakülte/ yüksekokul mezunu olanlar arasındadır. Bir önceki araştırma problemi ile birlikte değerlendirildiğinde öğrencilerin uyumsuz şemaları anne-baba eğitim seviyesine göre farkl1laşmaktadır. Eğitim seviyesi yükseldikçe şema puanlarında azalma görülmektedir. Ebeveynlerin eğitim seviyesi arttıkça uyumsuz şemaların öğrencilerde varlığı değişiklik göstermektedir. Alanyazında Harris ve Curtin (2002), yaptığı araştırmada ebeveynlik tutumlarının erken dönem uyumsuz şemalar ile ilişkili olduğunu bulmuştur. Algılanan ebeveynlik tutumları da eğitim seviyesi ilişkili olduğu düşünülmektedir ve erken dönem uyumsuz şemaların gelişiminde ebeveynlerin doğrudan ya da dolaylı olarak etkisi olduğu söylenebilir. Ayrıca McGinn vd. (2005) ebeveynin ihmal edici tutumunun bireylerde uyumsuz şemalarını etkilediğini bulmuşlardır. Bu araştırmada elde edilen bulgularında bu görüşü destekler nitelikte olduğu söylenebilir.

Araştırma bulgularına göre duygu düzenleme yöntemleri arasından içsel işlevsel duygu düzenleme yönteminde anlamlı fark olduğu görülmüştür. İçsel işlevsel duygu düzenleme yönteminde öğrencilerden anneleri okuryazar/ ilkokul mezunu ya da ortaokul mezunu olanların, babası lise ya da yüksekokul/ fakülte/ lisansüstü mezun olan öğrencilere göre daha az puan aldıkları görülmüştür. Anne eğitim seviyesi yükseldikçe öğrencilerde işlevsel duygu düzenleme yönteminin kullanımı daha çok görülmüştür. Ayrıca öğrencilerin baba eğitim düzeylerine göre duygu düzenleme yöntemlerinden içsel işlevsel duygu düzenleme yöntemi ve diş- 
sal işlevsel duygu düzenleme yönteminde anlamlı fark çıkmıştır. İçsel işlevsel duygu düzenleme yönteminde öğrencilerden babaları fakülte / yüksekokul / lisansüstü mezunu olanlar; babaları, okuryazar / ilkokul, ortaokul ya da lise mezunu olanlara göre daha fazla puan almışlardır. Dışsal işlevsel duygu düzenleme yönteminde babası lise mezunu olanlar; babası, okuryazar / ilkokul mezunu, ortaokul mezunu göre daha fazla puan almışlardır. Ayrıca babaları fakülte / yüksekokul / lisansüstü mezunu olanlar; babaları lise mezunu olanlara göre daha az puan almışlardır.

$\mathrm{Bu}$ bulgular birlikte değerlendirildiğinde anne- baba eğitim seviyesi yükseldikçe işlevsel duygu düzenleme yönteminin öğrenciler tarafından kullanımının arttığı, eğitim seviyesi azaldıkça ise işlevsel olmayan duygu düzenleme yönteminin arttığı görülmüştür.

Elde edilen diğer bulgularda duygu düzenleme yöntemleri ile uyumsuz şemalar arasında farklı yönde ve farklı düzeyde ilişkiler çıkmıştır: Iç̧sel işlevsel duygu düzenleme ile uyumsuz şemalar arasında genel olarak düşük düzeyde negatif yönlü, içsel işlevsel olmayan duygu düzenleme ile uyumsuz şemalar arasında genel olarak orta düzeyde pozitif yönlü, dışsal işlevsel duygu düzenleme ile uyumsuz şemalar arasında anlamlı ilişki bulunmayanların da olmasıyla birlikte genel olarak düşük düzeyde negatif yönlü ve dişsal işlevsel olmayan duygu düzenleme ile uyumsuz şemalar arasında genel olarak düşük düzeyde pozitif yönlü bir ilişki bulunmaktadir.

Araştırmanın son alt problemi doğrultusunda; Zedelenmiş Özerklik ve Performans şema alanının varyansın \%33'ünü açıkladığı ve içsel işlevsel olmayan duygu düzenleme yöntemini yordadığı ve Başkalarına Yönelimlilik şema alanın varyansın \%33'ünü açıkladığı ve içsel işlevsel olmayan duygu düzenleme yöntemini yordadığıgörülmüştür. Ayrıca Kopukluk ve Reddedilmişlik şema alanının varyansın \%21'sini açıkladığ levsel olmayan duygu düzenlemeyi yordadığı görülmüştür. Alt boyutlar ayrı ayrı incelendiğinde de içsel işlevsel olmayan duygu düzenleme yönteminin uyumsuz şemalardan Karamsarlık, Kusurluluk / Utanma, Duygusal Yoksunluk, Hastalık ve Tehditlere Karşı Dayanıksızlık, Yapışıklık ve Gelişmemiş Benlik ve Kuşkuculuk ve Kötüye Kullanılma alanlarının varyansın \%35'ini açıkladığı görülmüştür. Dışsal işlevsel olmayan duygu düzenleme yönteminin uyumsuz şemalardan Haklılık / Büyüklenmecilik, 
Yetersiz Özdenetim, Boyun Eğicilik, Karamsarlık, Yapışıklık ve Gelişmemiş Benlik ve Onay Arayıcılık alanlarının varyansın \%23'ünü açıkladığ1 görülmüştür. Yani adı geçen uyumsuz şemaların varlığı arttıkça öğrencilerde işlevsel olmayan duygu düzenleme yöntemlerinin kullanımının arttığı söylenebilir.

Çakır (2007) yaptığı çalışmasında bireylerde işlevsel olmayan şemalara sahip olanların işlevsel olmayan başa çıkma yöntemlerine sahip olduğunu bulmuştur. Bu araştırmadan elde edilen bulgular arasında da işlevsel olmayan şemalara sahip olan bireylerin işlevsel olmayan duygu düzenleme yöntemlerini kullanımı arttığı yer almaktadır. Çakır (2007)'ın bulgusunu bir yönden destekler nitelikte olduğu görülmektedir. İşlevsel olmayan şemaların varlığı, işlevsel olmayan davranışları ve işlevsel olmayan yöntemlerin kullanımını arttığı söylenebilir.

Sonuç olarak, erken dönem uyumsuz şemalar ile duygu düzenleme yöntemleri arasındaki ilişki incelenmiştir. Elde edilen bulgulara göre öğrencilerde işlevsel olmayan duygu düzenleme yöntemleri ile uyumsuz şemalar arasında anlamlı ilişki bulunmuştur. Ayrı ayrı öğrencilerin ebeveynlerinin eğitim seviyesi incelenmiş bulgular birlikte değerlendirildiğinde tutarlı sonuçlar elde edildiği görülmüştür. İlgili araştırmalardan ve yapılan bu çalışmadan yola çıkılarak erken dönem uyumsuz şemaların ve duygu düzenlemenin ergen yaş grubunda çalışılmasının rehberlik ve psikolojik danışma alanında yapılacak çalışmalara katkı sağlayabileceği söylenebilir. 


\section{EXTENDED ABSTRACT}

\section{An Investigation of The Relationship Between Early Maladaptive Schemas of Secondary School Students And Emotion Regulation Methods in Terms of Various Variables \\ Mustafa Kılınç - Ayşenur Önder \\ Mehmet Akif Ersoy University, Tefenni Imam Hatip Middle School}

Childhood experiences are the main basis of early maladaptive schemas. The schemas, developed in this period, emerge in the family of the individual. The individual's childhood experiences, circle of friends, his/ her school, environment etc. May cause schema'sformation (Young, 1990).

In addition, recent studies have attempted to clarify the formation of emotion regulation, and Thompson has described emotion regulation as follows: "Emotion regulation, extrinsic and intrinsic processes responsible formonitoring, evaluating and modifying emotional reactions, especially the irintensive and temporal features, to accomplish one'sgoals." (Thompson, 1994, p.27-28).

However, it is seen that there is noresearch conducted in the literaturea bout the predictors of the relationship between emotion regulation methods and early maladaptive schemas. Therefore, the problem statement of theresearch is thefollowing: "Is there a significant relationship between the emotion regulation methods and the early maladaptive schemas of middle school students?". In this direction, the aim of the study is to determine whetherthere is a correlation between the early periodin compatible schemas and emotion regulation methods of secondary school students studying in Burdur and whetherthere is a statistically significant difference between the scores obtained from the students according to some variables. In response to this general objective, the following questions were asked:

1. Are there any significant differences;

A) By gender,

B) According to educational level of mothers, 
C) According to educational level of fathers of students maladaptive schemas?

2. Are there any significant differences;

A) By gender,

B) According to educational level of the mothers,

C) According to educational level of the fathers emotion regulation process of the students?

3. Are there any significant relationships between early period maladaptive schemas and emotion regulation methots scores of these condary school students.?

4. Is there early period maladaptive schemas of secondary school students significantly predict students' emotion regulation methods?

\section{Method}

In thiss tudy, correlational comparative survey model wasused. The study group consisted of 1629 students studying in the center of Burdur in the 2017-2018 academic year. The data of the study were "Early Maladaptive Schema Questionnaires Set for Children and Adolescents between the ages of 10-16", "The Regulation of Emotions Questionnaire" and "Demographic Information Form" developed by researcher. The Cronboach alpha reliability coefficient of ÇEŞÖT was calculated to be .92. The Cronboach alpha reliability coefficient was calculated as .68. Frequency, percentile, arithmetic mean, standard deviation, Independent- Samples $t$ test, OneWay ANOVA, Pearson moments correlationcorrelation, linearregression analysis - Stepwise technique were used for data analysis.

\section{Results}

According to research results it is seen that there are more maladaptiv eschemas among male students and there is significant difference at gender based lower levels. Although there is not a significant difference according to gender based general scalepoints in emotion regulation methods, lower bases shows significant differences. Maladaptive schemas differbased on the educational level of parents and as the educationlevel rises, the presence of maladaptive schemas decreases. Another obtained finding is that 
among emotion regulation methods in students based on parental occupations, only interior functional emotional regulation Shows significant difference; it is discovered that at other lower levels does not show a significant difference. When the relation between early period maladaptive schemas and emotion regulation methods is studied, a relation is found at at middle and lower level and the direction of the relation showed variance to the lower levels. Lastly, maladaptive schemas' predictive level of emotion regulation is studied and it is seen that "Impaired Autonomy and Performance" and "Other Directedness" schema fields explain 33\% of the variance, and, "Disconnection and Rejection" schema field explains $21 \%$ of the variance. In addition, it was found thatnon-functional emotion regulation methods predict different maladaptive schemas.

\section{Kaynakça / References}

Akhun, M. (2012). Emotional aspects of psychological symptoms: The roles of parentıng attıtudes and emotıon dysregulatıon. Doktora Tezi, Hacettepe Üniversite, Ankara. 24.07.2017 tarihinde https://tez.yok.gov.tr sayfasından erişilmiş̧ir.

Boysan, M. (2012). Üniversite öğrencilerinde erken dönem uyumsuz şemalar, başa çıkma stilleri ve öznel iyi oluş arasındaki ilişkilere yönelik bir model sınaması Doktora Tezi, Ankara Üniversitesi, Ankara. 24.07.2017 tarihinde https://tez.yok.gov.tr sayfasından erişilmiştir.

Büyüköztürk, Ş., Çakmak, E.K., Akgün, Ö.E, Karadeniz, Ş. ve Demirel, F. (2012). Bilimsel araştırma yöntemleri. Ankara: Pegem

Calvete, E., Orue, I., and Hankin, B. L. (2014). A Longitudinal Test Of The Vulnerability-Stress Model With Early Maladaptives Schemas For Depressive And Social Anxiety Symptoms İn Adolescents. Journal Of Psychopathology And Behavioral Assessment, 37(1), 85-99.

Cole, P. M., Martin, S. E., and Dennis, T. A. (2004). Emotion regulation as a scientific construct: Methodological challenges and directions for child development research. Child Development, 75(2), 317-333.

Colman, L. K. (2010) Maladaptive schemas and depression severity: Support for incremental validity when controlling for cognitive correlates of depression. Master'sThesis, University Of Tennesse, Tennesse. 
Çakır, Z. (2007). Antisosyal kişilik bozukluğunda erken dönem uyumsuz şemalar, algılanan ebeveynlik biçimleri ve şema sürdürücü başa çıkma davranışları arasındaki ilişkiler: Şema terapi modeli çerçevesinde bir inceleme. Yüksek lisans tezi, Hacettepe Üniversite, Ankara. 27.07.2019 tarihinde https://tez.yok.gov.tr sayfasından erişilmiştir

Duy, B. ve Yıldız, M. A. (2014). Ergenler için duygu düzenleme ölçeği'ninTürkçe'yeuyarlanması. Turkish Psychological Counseling and Guidance Journal,5(41), 23-35.

Eberhart, N. K., Auerbach, R. P., Bigda-Peyton, J., and Abela, J. R. Z. (2011). Maladaptive schemas and depression: Test of stress generation and diathesis-stress models. Journal Of Social And Clinical Psychology, 30(1), 75-104.

Farrell, J. M., Shaw, I. A. and Reiss, N. (2012). Group Schema Therapy for Borderline Personality Disorder. In (M. van Vreeswijk, J. Broersen and M. Nadort Eds.), Handbook of Schema Therapy: theory, research and practice (p. 341-358). Chichester: WileyBlackwell.

George, D. and Mallery, M. (2010). SPSS forwindows step by step: A simpleguide and reference, 17.0 update (10a ed.) Boston: Pearson.

Gök, A. C. (2012). Associated factors of psychological well-being: Early maladaptive schemas, schema coping processes, and parenting styles. Yüksek Lisans Tezi, Orta Doğu Teknik Üniversitesi, Ankara. 21.09.2017 tarihinde https://tez.yok.gov.tr sayfasından erişilmiştir

Gross, J. J. (1998) The emerging field of emotion regulation: An integrative review. Review of General Psychhology, 2, 271-299.

Gross, J.J. and Thompson, R.A. (2007). Emotionregulation: Conceptualfoundations. (J. J. Gross and R. A. Thompson Ed.). Handbook of Emotion Regulation. New York: The Guild ford Press.

Gross, J.J. (2014). Emotion regulation: Conceptual and empirical foundations. In (J. J. Gross Ed.), Handbook Of Emotion Regulation. (2nd Ed., p. 3-20). New York: The Guildford Press.

Güner, O. (2013). 10-16 yaş çocuk ve ergenler için erken dönem uyumsuz şema ölçekler takımı (Çeşöt)'nın geçerlik, güvenirlik ve norm çalışması. Doktora Tezi, Marmara Üniversitesi, İstanbul. 28.05.2017 tarihinde https://tez.yok.gov.tr sayfasından erişilmiştir.

Harris, A. E. And Curtin, L. (2002). Parental perceptions, earlymal adaptive schemas, and depressive symptoms in young adults. Cognitive Therapy And Research, 26,405-416. 
Karasar, N. (2009). Bilimsel araştırma yöntemi, Ankara: Nobel

Kevlekçi, M. (2013). Erken dönem uyumsuz şemalar, tutumlar ve hatalı otomatik düşüncelerin depresif duygudurum ve intihar düşüncelerine etkisi. Yüksek Lisans Tezi, Haliç Üniversitesi, İstanbul. 24.07.2017 tarihinde https://tez.yok.gov.tr sayfasından erişilmiştir

Köse, B. (2009). Associations of psychological well-being with early maladaptive schemas and self-construals. Yüksek Lisans Tezi, Orta Doğu Teknik Üniversitesi, Ankara. 01.08.2017 tarihinde https://tez.yok.gov.tr sayfasından erişilmiştir

Livingstone, K., Harper, S., and Gillanders, D. (2009). An exploration of emotionregulation in psyhosis. Clinical Psychology and Psychotherapy, 16, 418-430.

McGinn, L. K., Cukor, D. and Sanderson,W. C. (2005). The relationship between parenting style, cognitive style and anxiety and depression: Does increased early adversity influence symptom severity through the mediating role of cognitivestyle. Cognitive Therapy and Research, 29(2), 219-242.

Phillips, K. F. V. and Power, M. J. (2007). A new self report measure of emotion regulation in adolescents: The regulation of emotion squestionnaire. Clinical Psychology and Psychotherapy, 14, 145-156.

Rafaeli, E., Bernstein, D.P., and Young, J.E. (2011). Şema terapi ayırıcı özellikleri. (M. Şaşıŏlu, Çev.), İstanbul: PsikonetYayınları.

Riso, L. P., Froman, S.E., Raouf, M., Gable, P., Maddux, R. E., Turini-Santorelli, N. ,..., Cherry, M. (2006). Thelong-termstability of earlymaladaptiveschemas. CognitiveTherapyAndResearch, 30, 515-529.

Sarıtaş, D. and Gençöz, T. (2011). Psychometric properties of young schema questionnaire short form 3: In a Turkish adolescent Sample. Journal Of CognitiveAndBehavioralPsychotherapies, 11(1), 83-96.

Sheppes, G., Scheibe, S., Suri, G., and Gross, J.J. (2011). Emotion-Regulation Choice. Psychological Science, 22, 1391-1396.

Tabachnick, B.G. and Fidell, L.S. (2013). Using multivariatestatistics. Boston: Pearson.

Thimm, J. C. (2011). Incremental validity of mal adaptive schemas overfivefactor model facets in the prediction of personality disorder symptoms. Personality And Individual Differences, 50, 777-782.

Thompson, R. A. (1991). Emotional regulation and emotional development. Educational Psychology Review, 3(4), 269-307. 
Thompson, R.A. (1994). Emotionregulation: A theme in search of definition. Monographs of thesocietyforresearch in childdevelopment, 59(2-3), 25-52.

Ünal, B. (2012). Early maladaptive schemas and well-being: importance of parenting styles and other psychological resources. Yüksek Lisans Tezi, Orta Doğu Teknik Üniversitesi, Ankara. 01.08.2017 tarihinde https://tez.yok.gov.tr sayfasından erişilmiştir

Yanık H., D. (2015). Erken dönem uyumsuz şemalar ile mizah arasındaki ilişki. Yüksek Lisans Tezi, Okan Üniversitesi, İstanbul. 24.07.2019 tarihinde https://tez.yok.gov.tr sayfasından erişilmiştir

Yiğit, İ. ve Erden, G. (2015). Çocukluk çağı istismar yaşantıları ile genel psikolojik sağlık arasındaki ilişkide erken dönem uyumsuz şemaların aracı rolü. Türkiye Psikoloji Dergisi, 30(75), 47-59.

Young, J. E. (1990). Cognitive therapy for personality disorders: A schema-focused approach. Sarasota: FL. Professional Resource

Young, J. E., Klosko, J. S., and Weishaar, M. E. (2003). Schema therapy: A Practitioner's Guide. New York: The Guilford Press.

\section{Kaynakça Bilgisi / Citation Information}

Kılınç, M. ve Önder, A. (2019). Ortaokul öğrencilerinin erken dönem uyumsuz şemaları ile duygu düzenleme yöntemleri arasındaki ilişkinin çeşitli değişkenler açısından incelenmesi. OPUSUluslararası Toplum Araştırmaları Dergisi, 14(20), 96-132. DOI: 10.26466/opus.542052 